\title{
SARPY BASIN WILDLIFE ECOLOGY STUDY
}

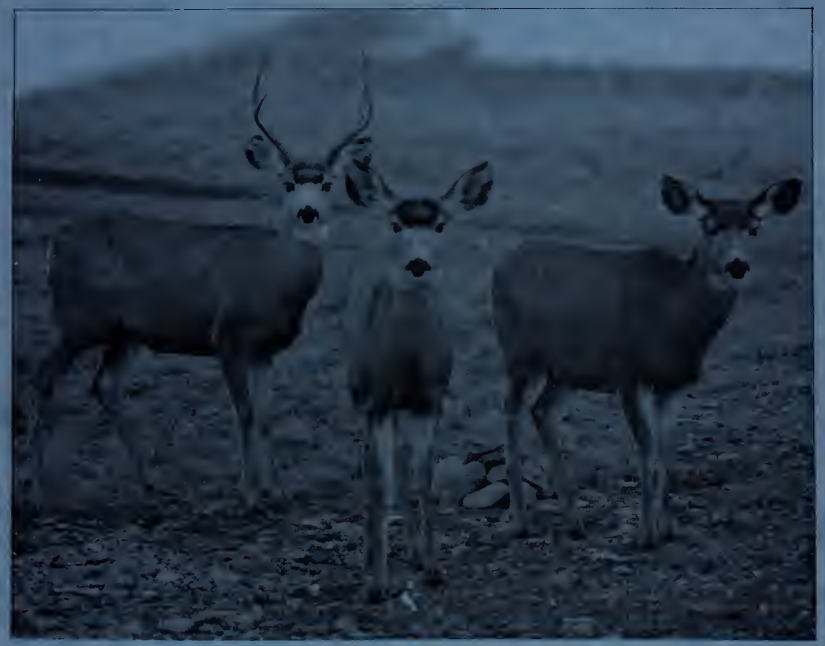

Peter R. Martin

Planning Ecologist

Environment and Information Division

February 1975
STATE ONCUMENTS FAI FRT'

กCT 14 xn?

MONTANA STATE

1515 E. 6 tii

HELENA, MON

MONTANA DEPARTMENT OF FISH AND GAME sponsored by CORMORANT CORPORAT.ION 


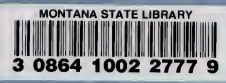

J 
List of Tables.................................. ii

List of Figures...........

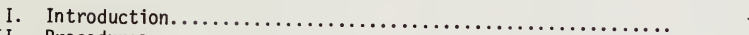

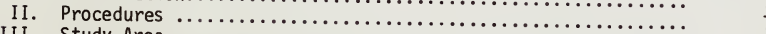

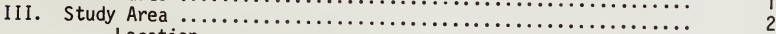

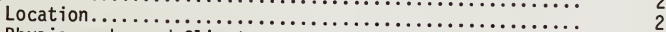

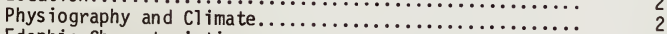

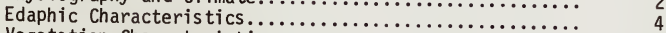

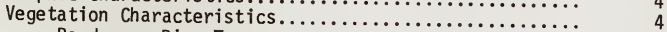

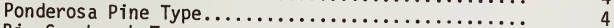

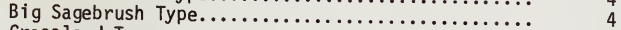

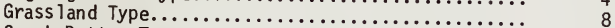

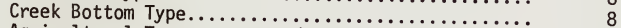

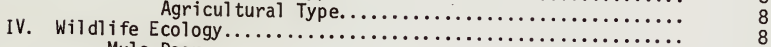

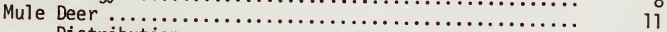

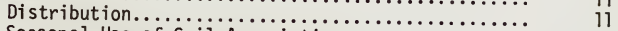

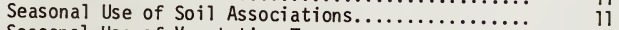

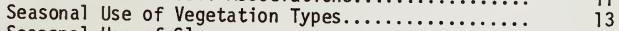

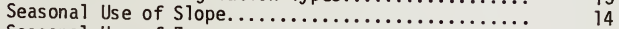

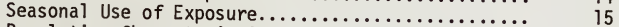

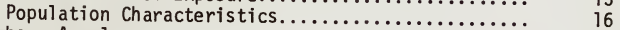

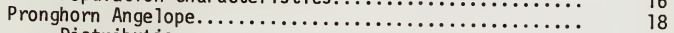

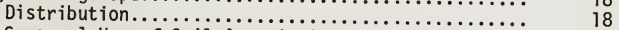

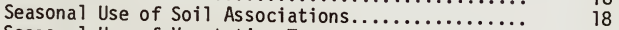

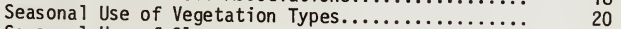

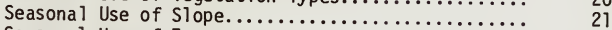

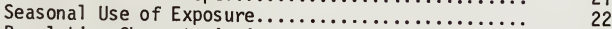

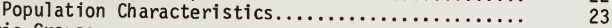

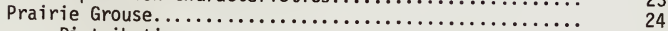

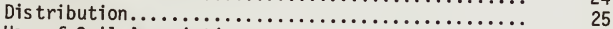

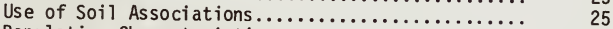

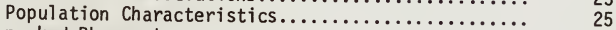

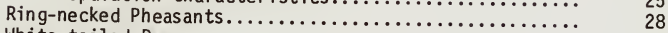

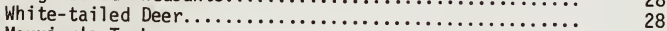

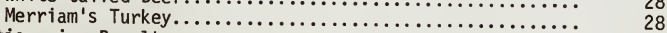

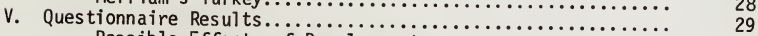

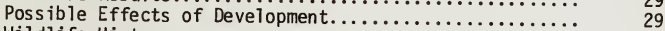

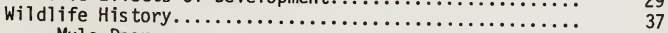

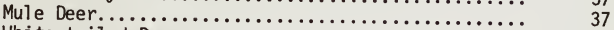

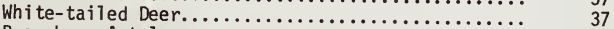

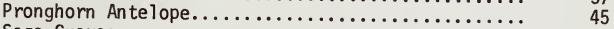

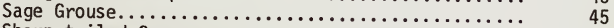

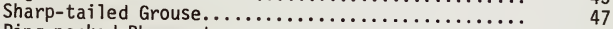

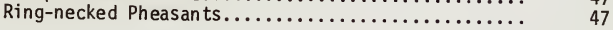


○

0 
Rabbits............................ 47

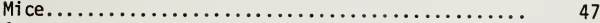

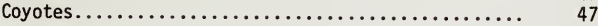

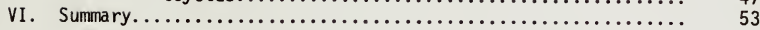

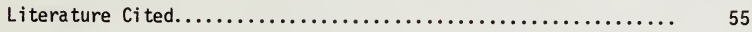

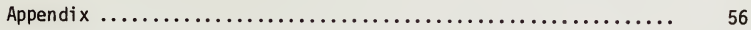


-

0

1

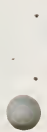




\section{LIST OF TABLES}

Table

Page

1. Seasonal distribution of mule deer by soil association...... 13

2. Seasonal use of vegetation types by mule deer.............. 14

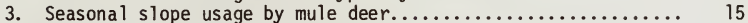

4. Seasonal distribution of mule deer according to exposure..... 16

5. Mule deer population characteristics in the Sarpy Creek

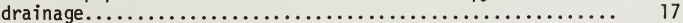

6. Seasonal distribution of antelope by soil association....... 20

7. Seasonal use of vegetation types by antelope............ 21

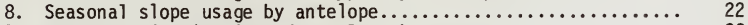

9. Seasonal distribution of antelope by exposure............ 23

10. Antelope population characteristics in the Sarpy Creek

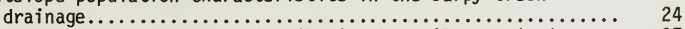

11. Sharptail dancing ground distribution by soil association... 27

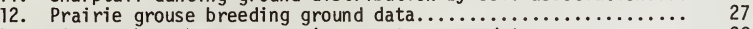

13. Ring-necked pheasant crowing count survey data............ 28

14. Historical antelope population characteristics in the Sarpy Creek vicinity............................ 45

Appendix

15. A brief description of the soils series found in the Sarpy

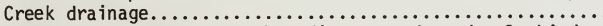

16. Location of prairie grouse breeding grounds and male birds

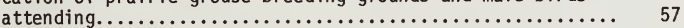

17. Population levels of selected species in the Sarpy Creek

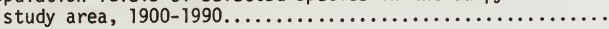


○

o

. 


\section{LIST OF FIGURES}

Figure

Page

1. Sarpy Basin wildlife ecology study area................ 3

2. General soil associations found in the Sarpy Creek draina..... 5

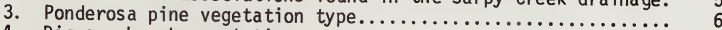

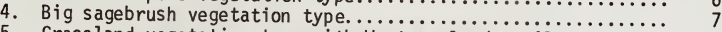

5. Grassland vegetation type wi th Westmoreland spoils bank

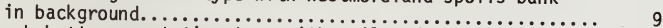

6. Creek bottom vegetation type with railroad fiii in

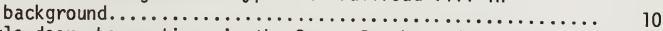

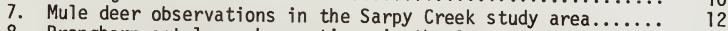

8. Pronghorn antelope observations in the Sarpy Creek study

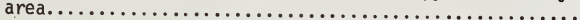

9. Prairie grouse breeding grounds, pheasant crow count routes and turkey observations in the Sarpy Creek

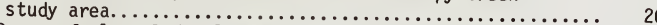

10. "Do you feel coal development will adversely affect wildl ife?"

11. "What level of coal development do you favor?" $\ldots \ldots \ldots \ldots$

12. "Do you feel reclamation of strip-mined land is possible in your area?".

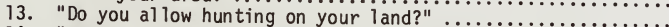

14. "What do you feel is the greatest threat to wildije in your area?"

15. Mule deer population levels $(1900-1990)$ determined by

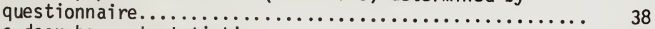

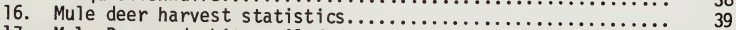

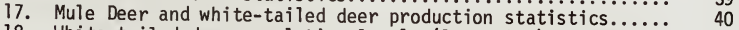

18. White-tailed deer population levels (1900-1990) determined by questionnaire................................... 41

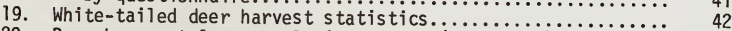

20. Pronghorn antelope population levels (1900-1990) determined by questionnaire..................... 43

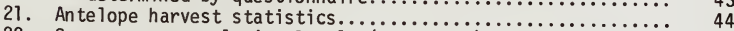

22. Sage grouse population levels $(1900-1990)$ determined

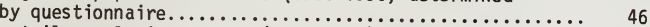

23. Sharptail population levels (1900-1990) determined by

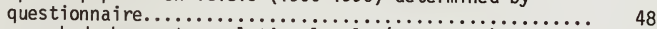

24. Ring-necked pheasant population ieveis $(1900-1990)$ determined by questionnaire...................... 49

25. Rabbit population levels (1900-1990) determined by

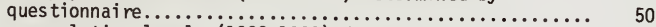

26. Mice population leveis $(1900-1990)$ determined by

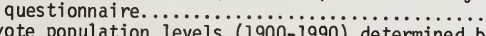

27. Coyote population levels $(1900-1990)$ determined by questionnaire. 
0

.

o

0 


\section{INTRODUCTION}

Strip mining of coal in the Fort Union formation has been proposed as a partial solution to the "energy crisis." This mining, along with associated energy conversion plants, transmission lines, and related facilities, is causing much concern, not only in Montana and the other producer states but the entire nation as well. The debate over the proposed Colstrip plants, which are less than 25 miles east of Sarpy Creek, is the first manifestation of this concern.

Many people are proposing that strip mining of coal for export only be allowed. Indeed, the official position of the state of Montana is, "...Montana people and their government would assent to the leasing of coal only if its combustion or conversion will take place near the nation's high energy demand areas. Consequently, both the lease terms and the characteristics of the coal deposits chosen for lease should dictate that the coal will be burned or converted at load centers."

Strip mining is currently taking place at the Westmoreland Mine located within the Sarpy Creek drainage. With the operation of this mine and the opening of others seemingly imminent in the area, the Sarpy Basin Wildlife Ecology Study was initiated in September 1973, with the following objectives:

(1) To determine the impact of existing and future surface mining operations on wildlife resources in the area.

(2) To ensure that fish and wildlife habitat values receive full recognition in any surface reclamation efforts that follow surface mining operations.

(3) To investigate possible modifications, additions or innovations in the surface mining reclamation processes to avoid unnecessary loss of wildlife habitat and develop techniques and procedures to enhance habitat through reclamation.

\section{PROCEDURES}

During the first year of this study, emphasis was placed on becoming familiar with physical aspects, vegetational composition, history of key wildlife species, and population characteristics of the various wildlife species of the study area. Soils information was obtained from the Soil Conservation Service offices of Big Horn, Rosebud and Treasure Counties. Vegetation types were determined through aerial and vehicular observations. These types are comparable to those described by Knapp (1972) in a similar area. 
Population characteristics of key wildlife species were obtained via personal observations from low-level aerial flights and vehicular surveys within the study area. At each observation, animals were classified as to sex and age. Vegetation type or subtype, class of slope, and exposure were noted and location was recorded to the nearest quarter section.

A questionnaire was distributed to farmers and ranchers who live or own land within the study area. Its primary purpose was to obtain a historical picture of various wildlife species from the resident's viewpoint. A few questions on the possible effects of strip mining and the potential for reclamation were included. Further information on wildlife history was obtained from records in the Department of Fish and Game office in Miles City.

\section{STUDY AREA}

\section{Location}

Sarpy Creek drainage is located in southeastern Montana approximately 18 airline miles northeast of Hardin, 57 airline miles southwest of Miles City, 65 airline miles east of Billings and 65 airline miles north of Sheridan, Wyoming.

Sarpy Creek (Figure 1) extends from its headwaters in the northeast corner of Big Horn County, through Treasure County, to its confluence with the Yellowstone River approximately 7 river miles east of the community of Hysham. The north boundary of the study area is Interstate Highway 94 and the remaining boundaries are the divides shared with surrounding drainages. These are Tullock Creek on the west and southwest, Rosebud Creek on the southeast and Armells and Reservation Creeks on the east.

\section{Physiography and $\mathrm{Climate}$}

Elevation ranges from 4820 feet in the Little Wolf Mountains along the southeast boundary to about 2650 feet at the intersection of Sarpy Creek and Inters tate 94.

Average annual precipitation is 10 to 14 inches over much of the area with 14 to 20 inches normal at higher elevations in the southern portion and along the Armells Creek divide (Jackson 1971). The average length of the frost-free season is approximately 130 days in the north and ranges to around 105 days in the southern portions (Caprio 1965).

Summers are generally hot and dry while winters are moderately cold and dry. At Hysham (elevation 2650 feet), temperatures range from an average of $18.6^{\circ} \mathrm{F}$ in January to $72.8^{\circ} \mathrm{F}$ in July. Precipitation averages 11.2 inches per year, with February the driest $(0.4$ inches) month and June the wettest (2.6 inches) month (Moshier and Fielder 1967). At Busby (elevation 3500 feet), which is about 10 miles south of the study area, a similar pattern exists with average temperatures ranging from $17.5^{6} \mathrm{~F}$ in January to $70.50 \mathrm{~F}$ in July. Average annual precipitation is 12.6 inches with February the driest month at 0.4 inches and June the wettest at 2.5 inches (Dightman 1972). 


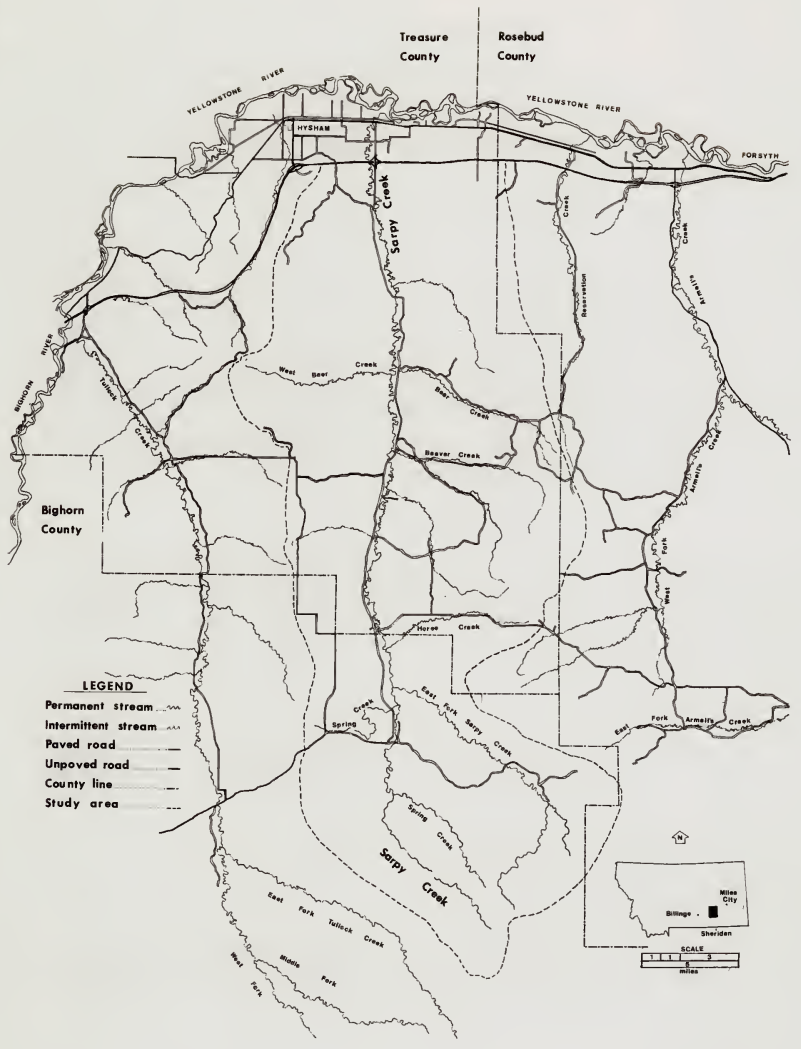

Figure 1. Sarpy Basin wildlife ecology study area. 


\section{Edaphic Characteristics}

There are six general suil associations (Figure 2) found within the drainage area. These are grouped into three major headings:

(1) Soils of high terraces, which include the Wanetta-Hesper association.

(2) Soils of rolling to hilly uplands on clay shale, which include the Pierre-Lismas association.

(3) Soils of rolling to rough, broken uplands on soft shale which include the Flasher-Bainville association in Treasure County and the Nelson-Alice association in Big Horn County, the Bainville-Midway association in Treasure County and the ThedalundMidway association in Big Horn County. The Wayden - Regent shale outcrop association and the Wibaux - Thedalund - Spearman association are also in this grouping. Complete details of all these soil associations are reported by Moshier and Fielder (1967) and Meshnick et al. (1972). Brief topography, surface runoff and vegetative descriptions from these surveys are included in Table 15 (appendix).

\section{Vegetation Characteristics}

Five vegetation types have been identified in the Sarpy Creek drainage. Four of these represent native vegetation and include the ponderosa pine, big sagebrush, grassland and creek bottom types. The fifth, agricultural, represents human influence in the form of introduced monocultures. All types have been divided into two or more subtypes. No quantitative analys is has been done at this time.

\section{Ponderosa Pine Type}

All areas where ponderosa pine (Pinus ponderosa) occurs are included in this type. It represents the most diversified of the types (Figure 3 ) and includes five subtypes:

(1) Ponderosa pine

(2) Big sagebrush (Artemisia tridentata)

(3) Grassland

(4) Rhus (Rhus trizobata)

(5) Juniper (Juniperus scopuZorum)

These subtypes were determined by the dominant shrub in the understory except for the ponderosa pine subtype which had no understory development and the grassland subtype which had no shrub development.

\section{Big Sagebrush Type}

This type is defined as those areas in which big sagebrush was the dominant overstory species (Figure 4). There are two subtypes: big sagebrush and grassland. The grassland subtype occurred as small patches of open grass surrounded by sagebrush. 


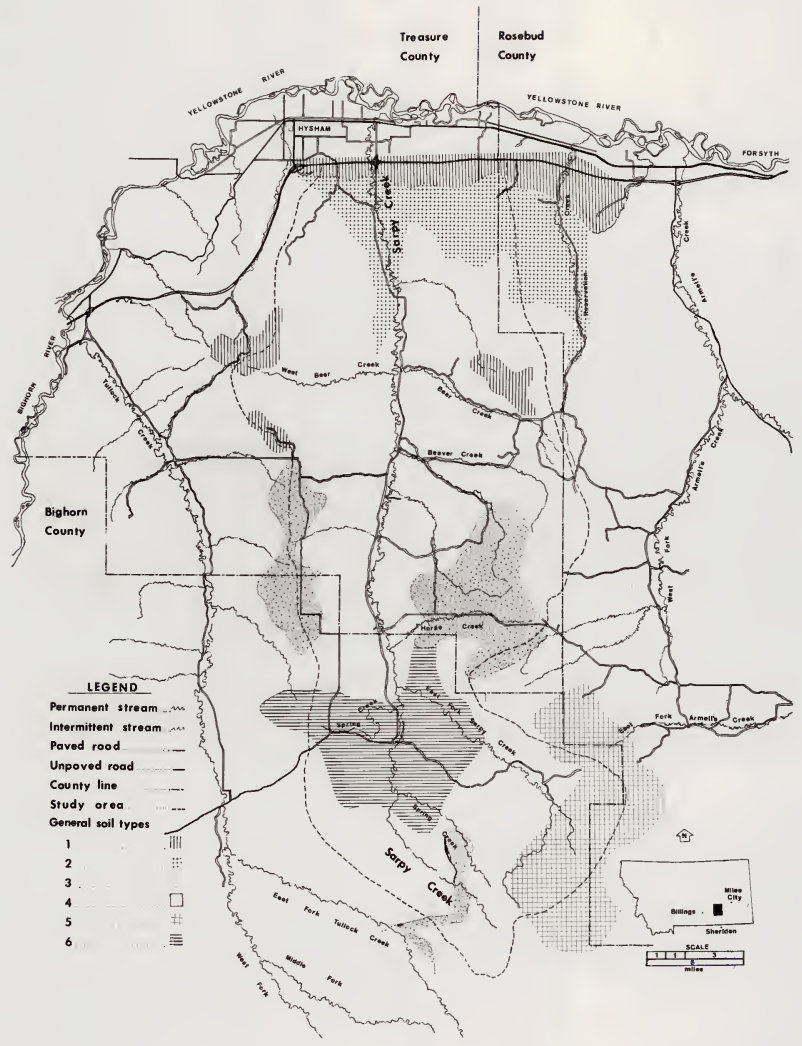

Figure 2. General soil associations found in the Sarpy Creek drainage. 


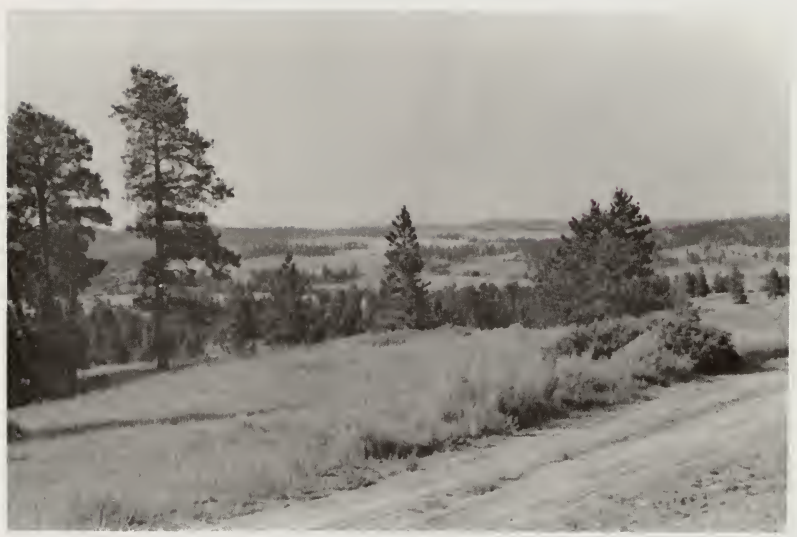

Figure 3. Ponderosa pine vegetation type. 
ธง

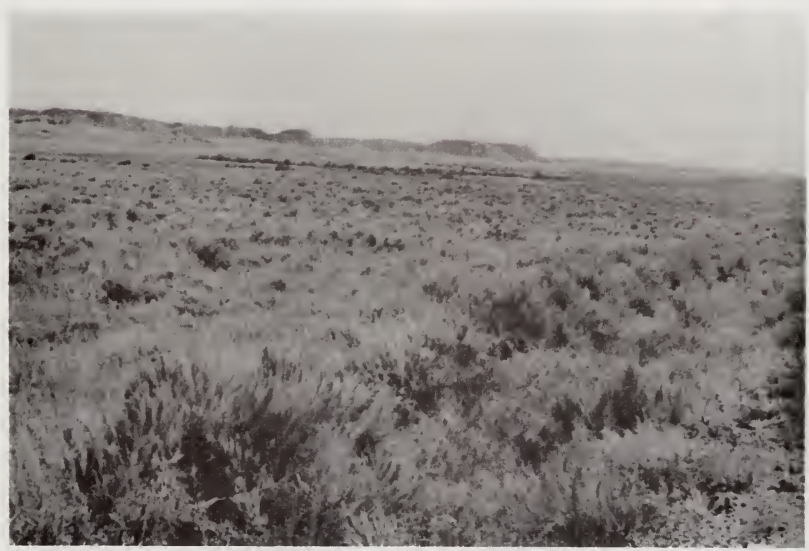

Figure 4. Big sagebrush vegetation type. 
Grassland Type

This type also has two subtypes, grassland and big sagebrush, and it is the antithesis of the previous type (Figure 5). It is defined as those areas where grass is the dominant species and sagebrush occurs only in isolated patches.

\section{Creek Bottom Type}

This type is confined to the Sarpy Creek bottom area (Figure 6) and the bottoms of the larger side drainages. It has two subtypes, cottonwood and shrub, determined by the status of plains cottonwood (Populus deltoides) trees in the area.

\section{Agricul tural Type}

This type was arbitrarily separated from the other types and classified into three subtypes based on the predominant adjacent type. The three subtypes are:
(1) Ponderosa pine
(2) Sagebrush-grassland
(3) Creek bottom

\section{WILDLIFE ECOLOGY}

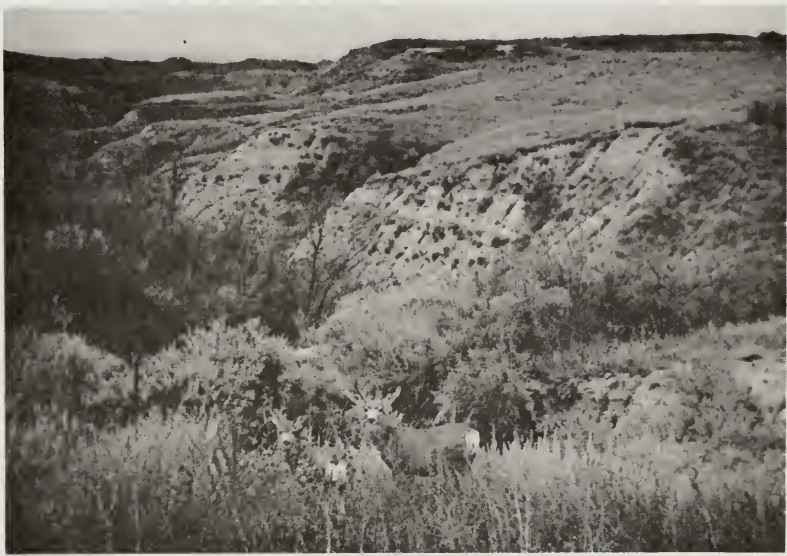




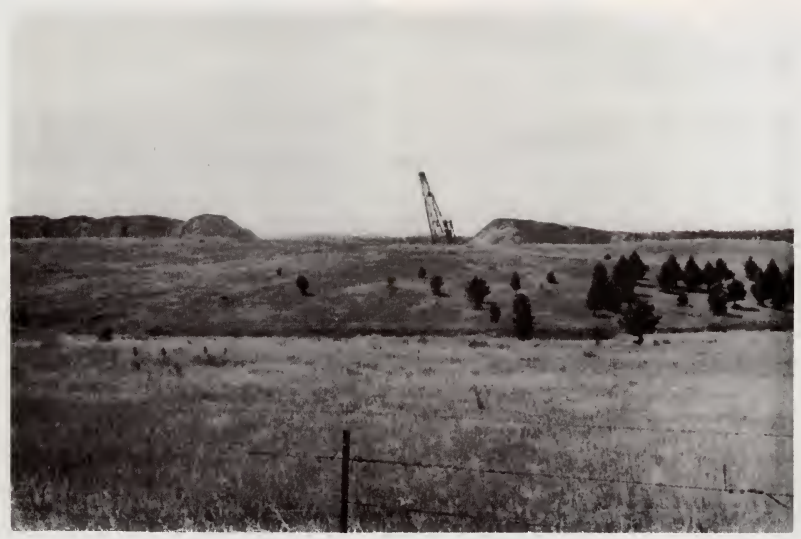

Figure 5. Grassland vegetation type with Westmoreland spoils bank in background. 


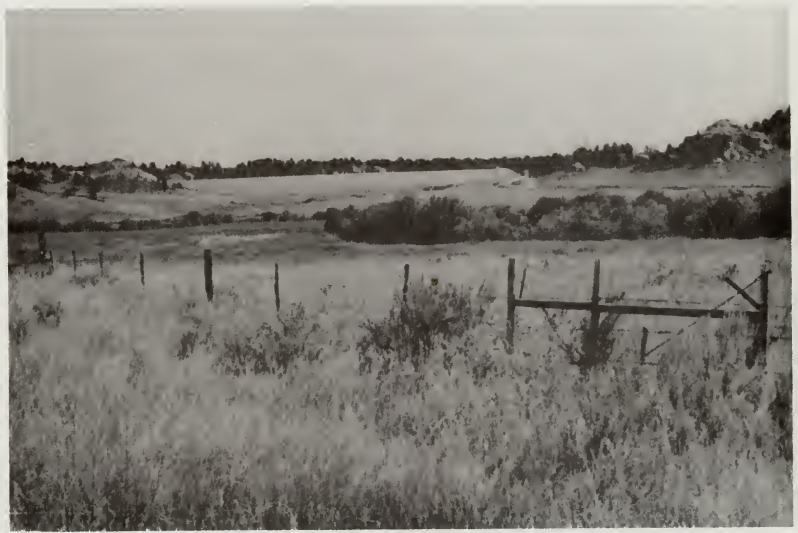

Figure 6. Creek bottom vegetation type with railroad fill in background. 
Mule deer (Odocoileus hemionus), pronghorn antelope (Antilocapra americana), and sharp-tailed grouse (Pediocetes phasianeilus) are the most common game species in the Sarpy Creek area. Merriam's turkey (Meleagris gallopavo merriami) occur in the southern portion of the area. White-tailed deer (Odocoileus virginiana) and ring-necked pheasants (Phasianus colchicus) are found primarily along the Sarpy Creek bottom. Sage grouse (Centrocercus urophasianus) and gray partridge (Perdix perdix) also occur in the area.

\section{Mule Deer}

A total of 531 mule deer in 92 observations, both ground and air, was sighted from December 1973 through November 1974 in the Sarpy Creek area. Observations were not spread evenly throughout the year. Consequently, some seasonal data are lacking.

\section{Distribution}

Individual observations of mule deer are shown in Figure 7 . Mule deer seem to be evenly distributed throughout the study area. The relatively small number of observations and the incomplete coverage of the area, both in time and space, preclude any attempt at drawing conclusions regarding seasonal movement. Dusek and McCann (1974) suggest that mule deer in the Bull Mountains, an area somewhat similar to the Sarpy Creek area, are nonmigratory.

Seasonal Use of Soil Associations

Plotted mule deer observations overlaid on the general soils map allowed the tabulation of the data presented in Table 1. The BainvilleMidway/Thedalund-Midway Association ( $B / T-M)$ showed the most usage in all seasons. It had 78 percent of all deer observed, compared to 7 percent for the Pierre-Lismas, Wayden-Regent and Flasher-Bainville/Nelson-Alice Associations ( $\mathrm{F}-\mathrm{B} / \mathrm{N}-\mathrm{A})$.

Winter: The B/T-M soils contained 86 percent of all mule deer observed and 79 percent of the observations. This may indicate a preference for this soil type. Statistical analysis involving a comparison of the relative areas of the different soil types to their use by deer, to be performed at a later date, should shed some light on this matter. The $F-B / N-A$ association was second with 8 percent of the deer and 16 percent of the observations.

Spring: Again the B/T-M association had the most usage with 81 percent of the deer observed and 69 percent of the observations. This was a slight decl ine from winter. The Wayden-Regent association was second with 19 percent of the observations and 12 percent of the deer.

Fall: This season showed the most diversity, with observations in all associations. The B/T-M association was dominant with 67 percent of the observations and 69 percent of the deer. The Pierre-Lismas association was second with 11 percent of the observations and 12 percent of the deer. 


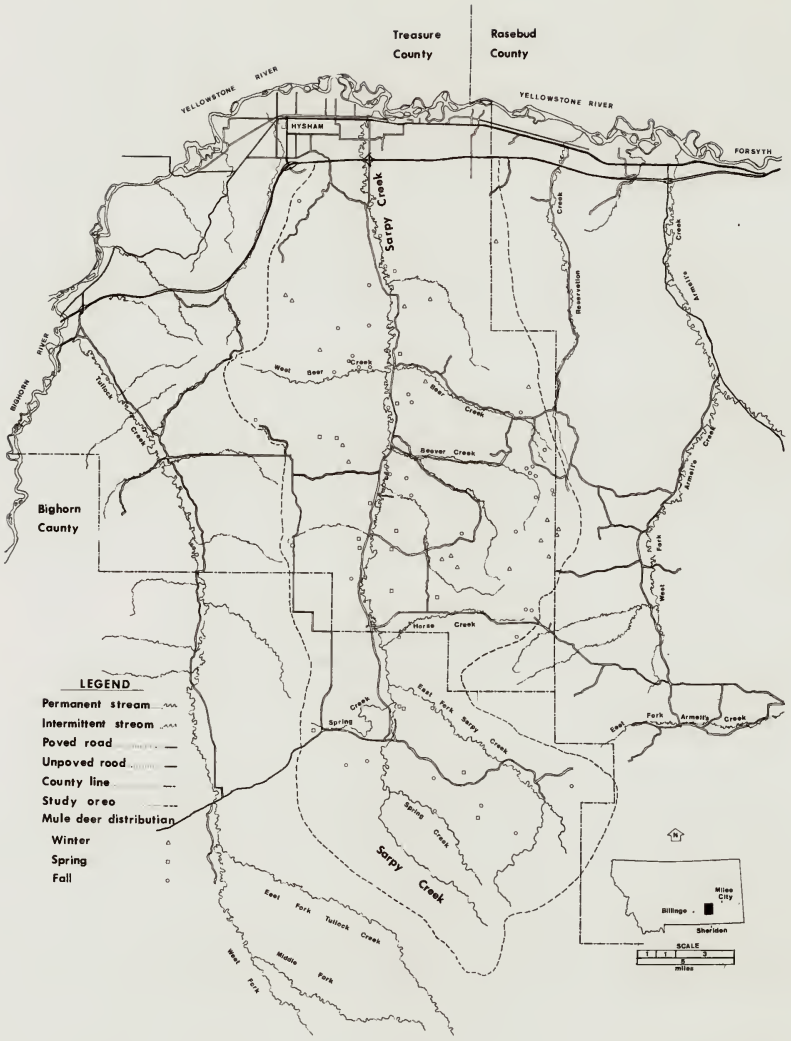

Figure 7. Mule deer observations in the Sarpy Creek study area. 
Table 1. Seasonal distribution of mule deer by soil association.

\begin{tabular}{|c|c|c|c|c|c|}
\hline $\begin{array}{l}\text { Soil } \\
\text { Association }\end{array}$ & $\begin{array}{l}\text { Winter } \\
(19-141) 1]\end{array}$ & $\begin{array}{l}\text { Spring } \\
(16-122) \\
\end{array}$ & $\begin{array}{l}\text { Fal1 } \\
(45-189) \\
\end{array}$ & $\begin{array}{l}\text { Total } \\
(79-452) \\
\end{array}$ & $\begin{array}{l}\text { Soil Association } \\
\text { Name5/ }\end{array}$ \\
\hline 1 & - & $6-2$ & $4-3$ & $4-2$ & Wanetta-Hesper $(T)$ \\
\hline 2 & $52 /-63 /$ & - & $11-12$ & $8-7$ & Pierre-Lismas $(T)$ \\
\hline 3 & $16-8$ & $6-4$ & $9-7$ & $10-7$ & $\begin{array}{l}\text { Flasher-Bainville }(T) \\
\text { Nelson-Alice }(B)\end{array}$ \\
\hline 4 & $79-86$ & $69-81$ & $67-69$ & $70-78$ & $\begin{array}{c}\text { Bainville-Midway (T)/ } \\
\text { Thedal und-Midway (B) }\end{array}$ \\
\hline 5 & - & $19-12$ & $9-9$ & $9-7$ & Wayden-Regent (B) \\
\hline 6 & - & - & $2-\operatorname{tr} \underline{4}$ & $1-\operatorname{tr}$ & $\begin{array}{l}\text { Wibaux-Thedal und- } \\
\text { Spearman (B) }\end{array}$ \\
\hline
\end{tabular}

1/ Number of observations - total mule deer observed

2/ Percent of observations

$3 /$ Percent of mule deer observed

4/ $\mathrm{tr}$ - trace, a value $<0.5$ percent

5/ (T) - Treasure County; (B) - Big Horn County

Seasonal Use of Vegetation Types

Overall, the ponderosa pine type showed the most usage with 40 percent of all observations and 50 percent of all deer observed (Table 2). This type was most heavily used in winter and spring when group sizes were largest. Ponderosa pine, big sage-grass and Rhus-grass subtypes had 15 percent, 12 percent and 12 percent, respectively, of the mule deer observed. The creek bottom type had 32 percent of the observations and 24 percent of the mule deer observed, while the agricultural type had 17 percent of the observations and 15 percent of the mule deer.

Winter: The ponderosa pine type, with 89 percent of mule deer observed, was used most heavily (Table 2). The ponderosa pine subtype had the highest percentage of observations ( 39 percent), but the Rhus-grass subtype had the highest numbers of deer ( 42 percent). The ease of sighting deer in this relatively open subtype may have biased this result. Knapp (1972) reported skunkbush sumac (Rhus trilobata) and big sagebrush (Artemisia tridentata) to be equally important in the winter diet of mule deer with each making up 24 percent of seasonal diet. 
Spring: The ponderosa pine type was again dominant with 70 percent of the mule deer observed, with use of the big sage-grass, its major subtype, at 32 percent. The big sage-grassland type had 16 percent.

Fal1: A dramatic switch in usage was noticed in this time period. Ponderosa pine fell off to only 8 percent usage while the creek bottom type increased from only 2 percent in both winter and spring to 58 percent. Use of the agricultural type also showed a large increase to 27 percent. This may reflect a movement of deer within the ir home range to the mesic bottoms and usage of new growth in winter wheat fields.

Table 2. Seasonal use of vegetation types by mule deer.

\begin{tabular}{|c|c|c|c|c|}
\hline & $\begin{array}{l}\text { Winter '73-'74 } \\
(18-132) 1]\end{array}$ & $\begin{array}{l}4 \text { Spring '74 } \\
(25-184) \\
\end{array}$ & $\begin{array}{c}\text { Fall } 14 \\
(49-215) \\
\end{array}$ & $\begin{array}{l}\text { Total } \\
(92-531)\end{array}$ \\
\hline Ponderosa Pine & $832 /-893$ I & $64-70$ & $12-8$ & $40-50$ \\
\hline Big Sage-Grassland & $6-2$ & $12-16$ & $2-2$ & $5-7$ \\
\hline Grassland & - & $12-6$ & $4-6$ & $5-5$ \\
\hline Creekbottom & $6-2$ & $4-2$ & $55-58$ & $32-24$ \\
\hline Agricultural & $6-8$ & $8-6$ & $27-27$ & $17-15$ \\
\hline $\begin{aligned} & \text { (P.Pine } \\
& \text { (Pig Sage-Grass } \\
& \approx \text { (Bigus-Grass } \\
& \text { (Rhus } \\
& \therefore \text { (Grassland } \\
& \therefore \text { (Juniper }\end{aligned}$ & $\begin{array}{c}39-27 \\
6-4 \\
22-42 \\
17-15 \\
-\end{array}$ & $\begin{array}{c}24-17 \\
24-32 \\
4-4 \\
8-14 \\
4-4\end{array}$ & $\begin{array}{l}8-6 \\
- \\
- \\
4-2 \\
-\end{array}$ & $\begin{array}{l}19-15 \\
8-12 \\
5-12 \\
8-9 \\
1-1\end{array}$ \\
\hline
\end{tabular}

1/ Number of deer observations - total deer observed

2) Percent of observations

3/ Percent of deer observed

Seasonal Use of Slope

During winter, steep slopes were most important (Table 3), with flat areas least important. Usage ranged from 66 percent of mule deer observed on steep slopes to 4 percent on the flats. Spring usage was relatively even between areas with any slope $(29,33$ and 34 percent for gentle, medium and steep, respectively) and flat areas were unimportant (4 percent of mule deer observed). Fall usage was the opposite of winter with flat areas receiving 68 percent of mule deer usage, while medium and steep slopes combined contained only 10 percent of the observations. This pattern corroborates the movement suggested earlier, i.e., from higher elevations in winter and spring to lower elevations in the fall. 
Table 3. Seasonal slope usage by mule deer.

\begin{tabular}{|c|c|c|c|c|}
\hline Slope & $\begin{array}{l}\text { Winter } \\
(17-116) \underline{1}\end{array}$ & $\begin{array}{c}\text { Spring } \\
(20-141)\end{array}$ & $\begin{array}{c}\text { Fal1 } \\
(49-215)\end{array}$ & $\begin{array}{c}\text { Total } \\
(86-472) \\
\end{array}$ \\
\hline Flat & $122 /-43 /$ & $5-4$ & $67-68$ & $42-33$ \\
\hline Gentle & $18-11$ & $40-29$ & $16-22$ & $22-21$ \\
\hline Medium & $29-19$ & $30-33$ & $8-4$ & $17-17$ \\
\hline Steep & $41-66$ & $25-34$ & $8-6$ & $19-29$ \\
\hline
\end{tabular}

1/ Number of observations - total mule deer observed

2) Percent of observations

3) Percent of mule deer observed

Seasonal Use of Exposure

Winter: Use of south, southeast and east slopes accounted for 63 percent of a 11 mule deer observed, with north and northwest slopes having 33 percent (Table 4). One might expect southwest and west slopes to have at least some usage. Perhaps the mild winter, with a distinct absence of snow cover, had something to do with this pattern.

Spring: Southwest and west exposure usage increased to 41 percent of deer observed during this time period, and south, southeast and east exposure usage declined to 48 percent. Northerly exposure usage declined from 33 percent in winter to 16 percent in spring. Spring weather was cold and wet.

Fa11: Because of their highly convoluted nature and many resultant microclimates, creek bottoms were classified as flat lands. The utilization of creek bottoms during fall was again evidenced with 68 percent of mule deer observed falling into the flat land category. The remaining observations were generally quite dispersed with southwest exposures receiving 14 percent of the usage. 
Table 4. Seasonal distribution of mule deer according to exposure.

\begin{tabular}{|c|c|c|c|c|}
\hline Exposure & $\begin{array}{l}\text { Winter'73-'74 } \\
(17-116) 1]\end{array}$ & $\begin{array}{l}\text { Spring '74 } \\
(20-141) \\
\end{array}$ & $\begin{array}{l}\text { Fall ' } 74 \\
(49-215)\end{array}$ & $\begin{array}{c}\text { Total } \\
(86-457) \\
\end{array}$ \\
\hline $\mathrm{N}$ & $18^{2} /-14 \underline{3}$ & $10-8$ & - & $6-6$ \\
\hline $\mathrm{S}$ & $12-8$ & $10-8$ & $4-4$ & $7-6$ \\
\hline$E$ & $35-28$ & $15-14$ & $4-2$ & $13-13$ \\
\hline W & - & $35-37$ & $6-6$ & $12-14$ \\
\hline $\mathrm{NE}$ & - & - & $8-7$ & $5-3$ \\
\hline NW & $12-19$ & - & $2-\operatorname{tr} \underline{4}$ & $4-5$ \\
\hline SE & $12-27$ & $20-26$ & - & $7-15$ \\
\hline SW & - & $5-4$ & $8-14$ & $6-5$ \\
\hline Flat & $12-4$ & $5-4$ & $67-68$ & $42-33$ \\
\hline
\end{tabular}

1/ Number of observations - total mule deer observed

2) Percent of observations

3/ Percent of mule deer observed

4) $\mathrm{tr}$ - trace, or $\overline{<} 0.5$ percent

\section{Pcpulation Characteristics}

Observations indicate that fawns per 100 doe ratios (Table 5) dropped slightly from the fall of $1973(86)$ to the winter of $73-74(82)$. This compares with 47 and 39 fawns per 100 does in the same fall and winter for the Bull Mountains (Dusek and McCann 1974) and 84 fawns per 100 does in the Missouri Breaks in 1963 (Mackie 1970). Knapp (1972) reported 62 fawns per 100 does in the winter of 1970-71 in the Fort Howes Ranger District of the Custer National Forest. The ratio dropped to 77 in the fall of 1974 in the Sarpy Creek area. Eustace (1974) reported 70 and 43 fawns per 100 does in hunting districts 720 and 722. Sarpy Creek is the boundary line between these two districts. The fawn per 100 doe ratio for the entire Montana Fish and Game Department administrative region 7 was 88:100 in 1973.

Fawns per 100 adults showed a decline from the fall of 1973 to the fall of 1974, with 62 and 59, respectively. The fawn per 100 adult ratio for region 7 in 1973 was 65:100 (Eustace 1974). The percentage of adult 
Table 5. Mule deer population characteristics in the Sarpy Creek drainage.

\begin{tabular}{|c|c|c|c|c|c|c|c|c|c|}
\hline Season & Bucks & Does & Fawns & Uncl. & Total & $\begin{array}{l}\text { Fawns: } \\
100 \text { Does } \\
\end{array}$ & $\begin{array}{l}\text { Fawns: } \\
100 \text { Adults } \\
\end{array}$ & $\begin{array}{l}\text { Bucks: } \\
100 \text { Does }\end{array}$ & $\begin{array}{l}\text { Does: } \\
100 \text { Deer } \\
\end{array}$ \\
\hline $\begin{array}{l}\text { Winter } \\
\text { Dec.'73-Feb.' } 74\end{array}$ & 12 & 44 & 36 & $\begin{array}{l}30 \frac{21}{31} \\
10 \underline{1}\end{array}$ & 132 & 81.8 & 54.5 & 27.3 & 43.1 \\
\hline $\begin{array}{l}\text { Fall } \\
\text { Sep. '74-Nov.' } 74\end{array}$ & 31 & 104 & 80 & - & 215 & 76.9 & 59.3 & 29.8 & 48.4 \\
\hline Fall'73l/ & 8 & 21 & 18 & - & 47 & 85.7 & 62.1 & 38.1 & 44.7 \\
\hline
\end{tabular}

1/ Based on observations by Stephen J. Knapp, environmental planning ecologist, Montana Department of Fish and Game

2/ Unclassified by sex or age

$\underline{3}$. Unclassified adults 
does in the fall populations increased from 44.7 in 1973 to 48.4 in 1974 , while the ratio of bucks per 100 does decreased from 38.1 in 1973 to 29.8 in 1974 .

The small sample sizes recorded for the fall and winter 1973-74 periods and one year's data are not sufficient for determining trends. It can be stated that fawn per doe ratios are hovering at the upper fair to lower good range (Eustace 1974) and compare favorably with other areas in eastern Montana. The Sarpy Creek area appears to have a healthier population than immediately surrounding areas.

\section{Pronghorn Antelope}

During 1974, 323 antelope were counted in 48 observations. Again, some seasonal data were not included because of a very small sample size.

Distribution

Seasonal antelope observations are shown in Figure 8 . There appears to be a major concentration in the area west of Sarpy Creek opposite the Horse Creek drainage. Several observations were grouped east of Sarpy Creek just south of Interstate 94 . No long range seasonal movement is evident.

Seasonal Use of Soil Associations

Three soil associations received the major share of the combined seasonal usage (Table 6): the Bainville-Midway/Thedalund-Midway (B/T-M) Association ( 56 percent of antelope observations and 55 percent of antelope observed); the Flasher-Bainville/Nelson-Alice ( $F-B / N-A)$ association ( 32 and 24 percent, respectively); and the Pierre-Lismas ( $\mathrm{P}-\mathrm{L}$ ) association ( 10 and 18 percent, respectively).

Spring: The B/T-M association had 68 percent of the antelope observed, while the F-B/N-A association had 19 percent. They had 60 and 32 percent of the observations, respectively.

Summer: Percentages of antelope observed were evenly distributed between the three major associations with 36 percent for $F-B / N-A, 34$ percent for $P-L$ and 30 percent for $B / T-M$ associations. This represents $a$ decrease in $B / T-M$ and a large increase in $P-L$ soils.

Fal1: Observations on $B / T-M$ soils increased to 52 percent of the total, while $\mathrm{P}-\mathrm{L}$ and $\mathrm{F}-\mathrm{B} / \mathrm{N}-\mathrm{A}$ decreased to 25 percent and 24 percent, respectively. 


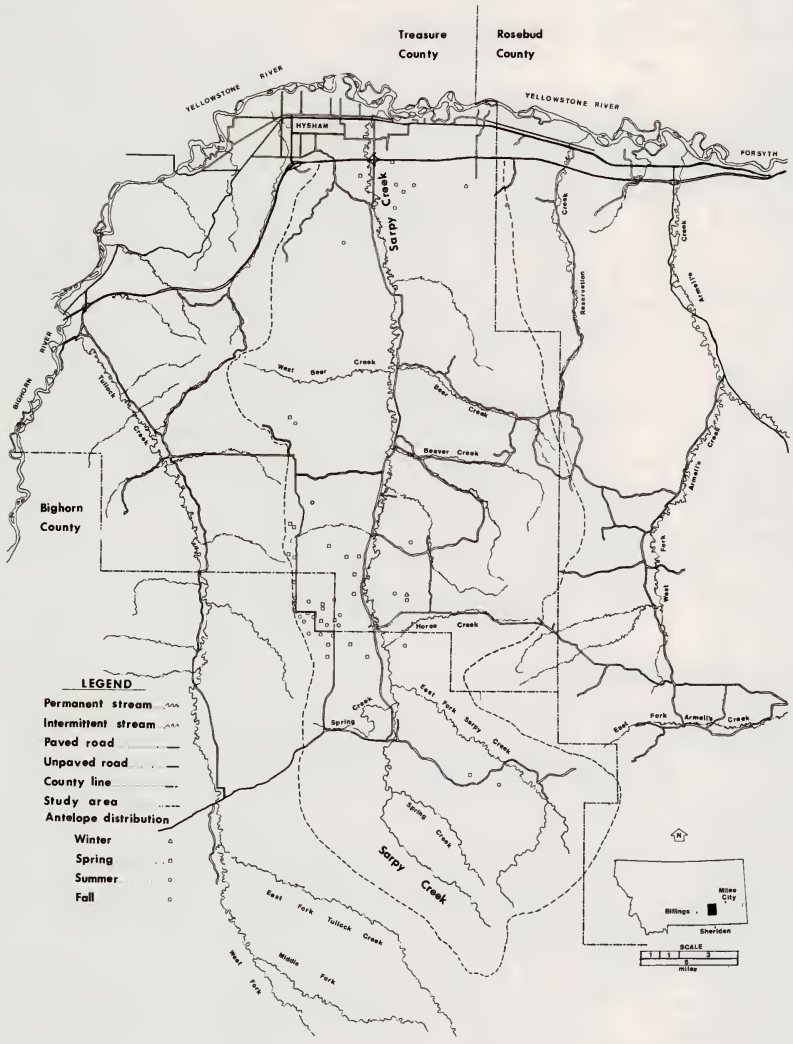

Figure 8. Pronghorn antelope observations in the Sarpy Creek study area. 
Table 6. Seasonal distribution of antelope by soil association.

\begin{tabular}{|c|c|c|c|c|c|}
\hline $\begin{array}{l}\text { Soil } \\
\text { Association } \\
\end{array}$ & $\begin{array}{l}\text { Spring } \\
(25-140) ! /\end{array}$ & $\begin{array}{r}\text { Summer } \\
(12-56)\end{array}$ & $\begin{array}{l}\text { Fall } \\
(12-149)\end{array}$ & $\begin{array}{l}\text { Total } \\
(49-345) \\
\end{array}$ & $\begin{array}{l}\text { Soil Association } \\
\text { Name } 4 /\end{array}$ \\
\hline 1 & $42 /-93 /$ & - & - & $2-4$ & Wanetta-Hesper (T) \\
\hline 2 & $4-4$ & $17-34$ & $17-25$ & $10-18$ & Pierre-Lismas $(T)$ \\
\hline 3 & $32-19$ & $42-36$ & $33-24$ & $35-24$ & $\begin{array}{l}\text { Flasher-Bainville (T) } \\
\text { Nelson-Alice (B) }\end{array}$ \\
\hline 4 & $60-68$ & $41-30$ & $50-52$ & $53-55$ & $\begin{array}{l}\text { Bainville-Midway (T)/ } \\
\text { Thedal und-Midway (B) }\end{array}$ \\
\hline 5 & - & - & - & - & Wayden-Regent (B) \\
\hline 6 & - & - & - & - & $\begin{array}{l}\text { Wibaux-Thedal und- } \\
\text { Spearman (B) }\end{array}$ \\
\hline \multicolumn{6}{|c|}{$\begin{array}{l}\text { 1/ Number of observations - total antelope observed } \\
\frac{2}{3 /} \text { Percent of observations } \\
\text { (1/ Percent of antelope observed } \\
\text { (T) - Treasure County; (B) - Big Horn County }\end{array}$} \\
\hline
\end{tabular}

Seasonal Use of Vegetation Types

The combined data show that the big sage-grassland and grassland types were most important to antelope (Table 7). The big sage-grassland type had the highest percentage of antelope with 49 percent, while the grassland type had the most observations with 52 percent. Agricultural and ponderosa pine types received very little to moderate usage while the creek bottom type had no recorded observations.

Spring: The grassland type was the recipient of most of the antelope usage, with 64 percent of the observations and 69 percent of the antelope observed. The big sage-grassland type was second in both categories, with 29 percent and 24 percent, respectively. The agricultural type usage was 7 percent and 7 percent, respectively.

Summer: A trend was established with usage in the big sage-grassland type increasing to 38 percent of the observations and 54 percent of the antelope observed. Usage decreased in the grass land type to 62 percent and 46 percent, respectively. No observations were recorded in the other vegetative types. 
Fal1: The trend established in summer continued with usage in the big sage-grassland type increasing further to 58 percent of the observations and 73 percent of the antelcpe. The grassland type usage decreased to 17 percent and 5 percent, respectively, and was replaced in importance by the agricultural type with 17 percent and 16 percent, respectively. The ponderosa pine type also received some usage, making fall the season of widest diversification.

Table 7. Seasonal use of vegetation types by antelope.

\begin{tabular}{|c|c|c|c|c|}
\hline & $\begin{array}{l}\text { Spring ' } 74 \\
(28-146) \underline{ }\end{array}$ & $\begin{array}{c}\text { Summer }^{\prime} 74 \\
(8-28)\end{array}$ & $\begin{array}{l}\text { Fal1 } 74 \\
(12-149)^{1}\end{array}$ & $\begin{array}{l}\text { Tota1 } \\
(48-323) \\
\end{array}$ \\
\hline Ponderosa Pine & - & - & $8-5$ & $2-3$ \\
\hline Big Sage-Grassland & $292 /-24^{3 /}$ & $38-54$ & $58-73$ & $38-49$ \\
\hline Grass 1 and & $64-69$ & $62-46$ & $17-5$ & $52-38$ \\
\hline Creek Bottom & - & - & - & - \\
\hline Agricultural & $7-7$ & - & $17-16$ & $8-10$ \\
\hline
\end{tabular}

1/ Number of observations - total observed

2/ Percent of observations

3/ Percent of antelope observed

Seasonal Use of Slope

Gentle and medium slopes accounted for 85 percent of antelope observations and 92 percent of the antelope observed (Table 8 ). Steep and flat lands had 7 and 2 percent of the antelope observed. The relatively small use of flat lands, normally preferred by antelope, is due to the paucity of that 1 and form in the area and the apparent avoidance of the flat creek bottoms by antelope.

Spring: During spring use was spread throughout the area, ranging from a low of 4 percent of observations on flat land to 54 percent on medium slopes. Percentage of antelope observed followed a similar pattern, ranging from 3 percent on flat land to 65 percent on medium slopes.

Summer: Usage of medium slopes increased to 75 percent of observations and 89 percent of antelope observed. Flat and gentle slopes, each with 13 percent of the observations, had 4 percent and 7 percent of the antelope observed, respectively. 
Fal1: Each of two categories had 50 percent of the antelope observations. Seventy percent of observed antelope were on gentle slopes, while 30 percent were on medium slopes.

Table 8. Seasonal slope usage by antelope.

\begin{tabular}{|c|c|c|c|c|}
\hline Slope & $\begin{array}{l}\text { Spring } \\
(28-146) 1 /\end{array}$ & $\begin{array}{r}\text { Summer } \\
(8-28) \\
\end{array}$ & $\begin{array}{l}\text { Fal1 } \\
(12-149) \\
\end{array}$ & $\begin{array}{l}\text { Total } \\
(48-323) \\
\end{array}$ \\
\hline Flat & $42 /-3$ l & $13-4$ & - & $4-2$ \\
\hline Gentle & $25-17$ & $13-7$ & $50-70$ & $29-41$ \\
\hline Medium & $54-65$ & $75-89$ & $50-30$ & $56-51$ \\
\hline Steep & $18-15$ & - & - & $10-7$ \\
\hline
\end{tabular}

1/ Number of observations - total antelope observed

2) Percent of observations

3) Percent of antelope observed

\section{Seasonal Use of Exposure}

Spring: Use of southerly exposures amounted to 50 percent of all observations and 57 percent of all antelope observed (Table 9). The northerly exposures accounted for 15 percent of observations and 14 percent of antelope observed. Western exposures had 29 percent of all the antelope observed, while eastern exposures had 27 percent.

Summer: Northern exposures increased in importance to 51 percent of antelope observations and 71 percent of all antelope observed. Western exposures had 25 percent of antelope observed, while eastern exposures had 35 percent.

Fal1: Use of northerly exposures remained above that of southerly exposures, with 45 percent and 5 percent of antelope observed, respectively. Easterly exposure usage came to the fore with 75 percent of the observations and 61 percent of the antelope observed. 
Table 9. Seasonal distribution of antelope by exposure.

\begin{tabular}{|c|c|c|c|c|}
\hline Exposure & $\begin{array}{l}\text { Spring } \\
(\underline{28-146)} \underline{ }\end{array}$ & $\begin{array}{r}\text { Summer } \\
(8-28) \\
\end{array}$ & $\begin{array}{l}\text { Fal1 } \\
(12-149)\end{array}$ & $\begin{array}{l}\text { Tota1 } \\
(48-323)\end{array}$ \\
\hline $\mathrm{N}$ & $112 /-10 \underline{3} /$ & $13-25$ & - & $8-7$ \\
\hline$S$ & $32-32$ & $13-11$ & - & $21-16$ \\
\hline $\mathrm{E}$ & $18-9$ & - & $33-46$ & $19-25$ \\
\hline W & $14-18$ & - & $8-3$ & $10-10$ \\
\hline NE & $4-4$ & $25-21$ & $17-10$ & $10-9$ \\
\hline NW & - & $13-25$ & $17-35$ & $6-18$ \\
\hline SE & $7-14$ & $25-14$ & $25-5$ & $15-10$ \\
\hline SW & $11-11$ & - & - & $6-5$ \\
\hline Flat & $4-3$ & $13-4$ & - & $4-2$ \\
\hline
\end{tabular}

1/ Number of observations - total antelope observed

2/ Percent of observations

$\underline{3}$ / Percent of antelope observed

Population Characteristics

The only two seasons in which antelope are easily placed in age and sex categories are summer and fall. Observations from these two seasons are shown in Table 10. Antelope production appears to be quite poor, 59 fawns per 100 does in summer and it gets worse, declining to 38 fawns per 100 does by fa11. Dusek and McCann (1974) reported 31 fawns per 100 does in the Bul1 Mountains. Fawns per 100 does in Region 7 in 1973 were 93:100 (Wentland 1974). The last year in which the Sarpy Creek area was surveyed by the Montana Department of Fish and Game was 1972. That year fawns per 100 doe ratios for hunting districts 720 and 722 were 40 fawns per 100 does in 720 and 65:100 in 722 (Wentland 1974).

Fawns per 100 adult ratios declined from 44 to 28 from summer to fall. Buck numbers in the population remained stable at 35 per 100 does. In 1972 there were 31 fawns per 100 adults and 29 bucks per 100 does in district 720. There were 52 fawns per 100 adults and 24 bucks per 100 does in district 722 (Wentland 1974). In the Bull Mountains there were 24 fawns per 100 adults and 27 bucks per 100 does in 1973 (Dusek and McCann 1974). 
This area appears to have relatively poor antelope populations, but that is not surprising because of the lack of large areas of relatively flat land covered with sagebrush. It does seem to be slightly better than the Bull Mountains.

Table 10. Antelope population characteristics in the Sarpy Creek drainage.

\begin{tabular}{|c|c|c|c|c|c|c|c|c|c|}
\hline & Bucks & Does & Fawns & Uncl. & Total & $\begin{array}{c}\text { Fawns: } \\
100 \\
\text { Does } \\
\end{array}$ & $\begin{array}{c}\text { Fawns: } \\
100 \\
\text { Adults } \\
\end{array}$ & $\begin{array}{c}\text { Bucks } \\
100 \\
\text { Does } \\
\end{array}$ & $\begin{array}{c}\text { Does: } \\
100 \\
\text { Antelope } \\
\end{array}$ \\
\hline Summer ' 74 & 10 & 29 & 11 & - & 56 & 58.6 & 43.6 & 34.5 & 51.7 \\
\hline $\mathrm{Fall} \cdot 74$ & 30 & 86 & 33 & - & 149 & 38.4 & 28.4 & 34.9 & 57.7 \\
\hline
\end{tabular}

\section{Prairie Grouse}

During March and April 1974, sixteen sharptail dancing grounds were located within or near the study area. A total of 203 male birds was observed on dancing grounds. Three sage grouse strutting grounds were found with a total of 35 adult males attending.

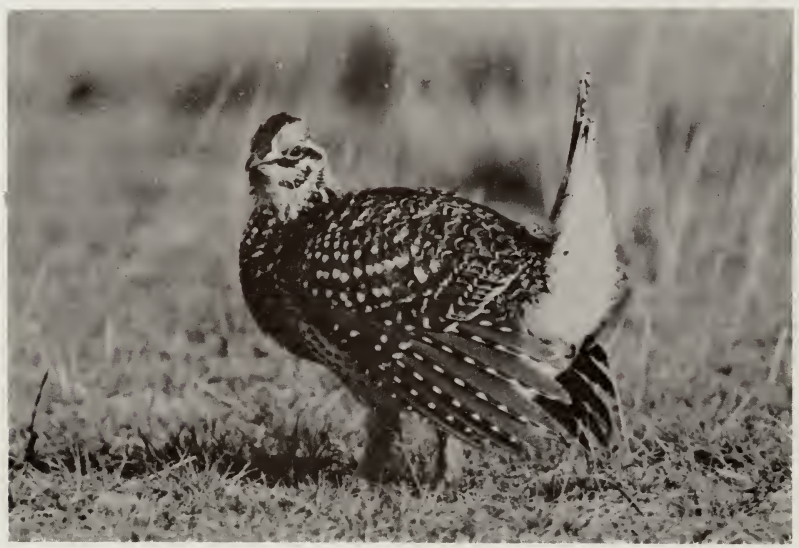


Distribution

Sharptail dancing grourds located in 1974 are shown in Figure 9. These grounds seem to be more prevalent in the southern portion of the study area. An attempt will be made to locate every dancing ground in the coming year. Sage grouse strutting grounds are all within a 3 -mile radius centered just west of Sarpy Creek about midway between the Horse Creek and Burnt Creek roads.

Use of Soil Associations

Dancing grounds were located in three of the six soil associations. The highest number of grounds, eight, was located in the Bainville-Midway/ Thedalund-Midway association (Table i1). It also had the highest number of adult males per ground, 13.1. The Flasher-Bainville/Nelson-Alice association had 5 grounds with 12.0 birds per ground. The only other association with sharptails was the Wibaux-Thedalund-Spearman association with 3 grounds and 12.7 birds per ground.

All three sage grouse strutting grounds were in the Bainville-Midway/ Thedalund-Midway association. There were 11.7 males per ground.

\section{Population Characteristics}

Breeding population information (numbers of male birds on grounds) is summarized in Table 12 . Numbers of birds on individual grounds is presented in Appendix Table 16. The average number of male birds per sharptail dancing grounds (12.7) is below that reported for grounds in Region 7 in 1973 (17.2), but above that reported for the Colstrip route $(9.8)$ which is just east of the study area (Wallestad 1974). Numbers of sage grouse males per strutting ground (11.7) were considerably below levels reported for other regions of southeastern Montana (43.2) in 1973. This reinforces the impression that this area is not prime sage grouse habitat.

Only four sharptail broods were observed during this reporting period, a total of 13 juveniles with 4 hens. This is 3.25 young per brood, and is substantially below the 6.7 young per brood recorded in Region 7 in 1973 (Wallestad 1974). This sample size is too small for reliable conclusions, but the low figure could be the result of adverse spring weather. No sage grouse broods were observed. 


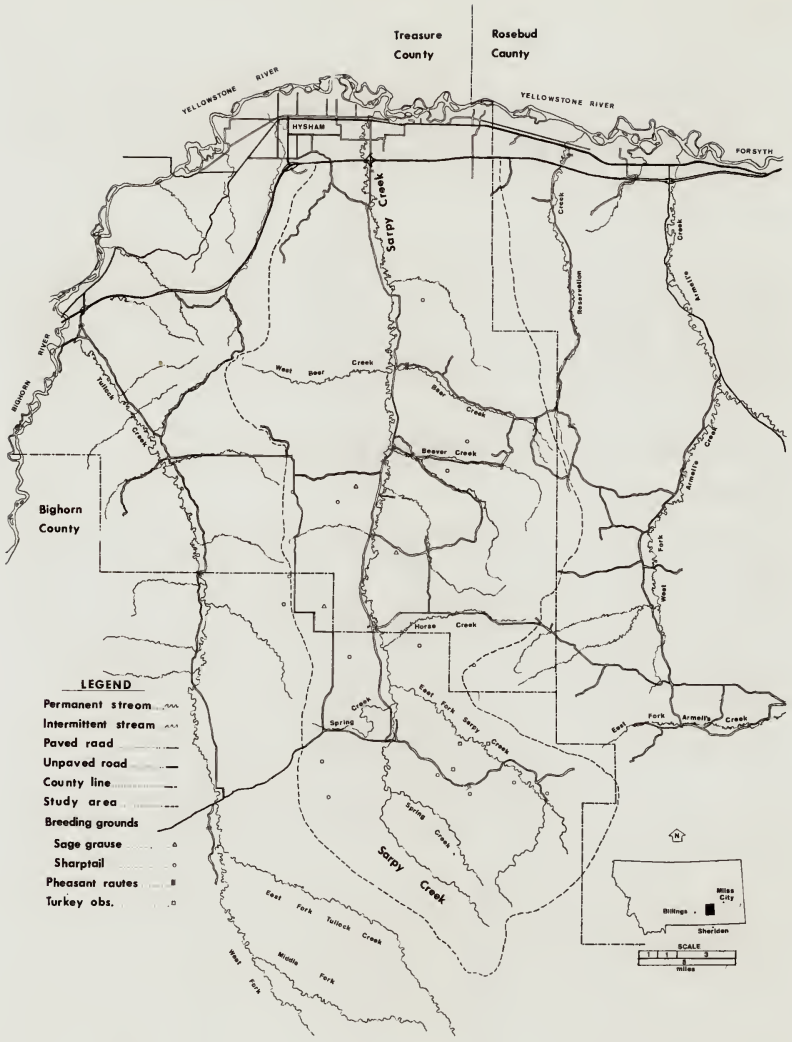

Figure 9. Prairie grouse breeding grounds, pheasant crow count routes and turkey observations in the Sarpy Creek study area. 
Table 11. Sharptail dancing ground distribution by soil association.

\begin{tabular}{|c|c|c|c|c|}
\hline & Grounds & Male Birds & $\begin{array}{l}\text { Male Birds/ } \\
\text { Ground }\end{array}$ & Soil Association \\
\hline 1. & - & - & - & Wanetta-Hesper ( $\mathrm{T}) \underline{\underline{ }}$ / \\
\hline 2. & - & - & - & Pierre-Lismas ( $T$ ) \\
\hline 3. & 5 & 60 & 12.0 & $\begin{array}{l}\text { Flasher-Bainville }(T) / \\
\text { Nelson-Alice (B) }\end{array}$ \\
\hline 4. & 8 & 105 & 13.1 & $\begin{array}{l}\text { Bainville-Midway ( }(T) / \\
\text { Thedal und-Midway (B) }\end{array}$ \\
\hline 5. & - & - & - & Wayden-Regent (B) \\
\hline 6. & 3 & 38 & 12.7 & Wibaux-Thedal und-Spearman ( $B$ \\
\hline
\end{tabular}

Table 12. Prairie grouse breeding ground data.

\begin{tabular}{|c|c|c|c|c|}
\hline Species & $\begin{array}{l}\text { Hunting } \\
\text { District }\end{array}$ & $\begin{array}{l}\text { Number of } \\
\text { Grounds }\end{array}$ & $\begin{array}{l}\text { Male } \\
\text { Birds } \\
\end{array}$ & $\begin{array}{l}\text { Birds/ } \\
\text { Ground } \\
\end{array}$ \\
\hline \multirow{3}{*}{$\begin{array}{l}\text { Sharptail } \\
\text { Grouse }\end{array}$} & 720 & 7 & 63 & 13.3 \\
\hline & 722 & 9 & 110 & 12.2 \\
\hline & Study Area & 16 & 203 & 12.7 \\
\hline \multirow{3}{*}{$\begin{array}{l}\text { Sage } \\
\text { Grouse }\end{array}$} & 720 & 2 & 19 & 9.5 \\
\hline & 722 & 1 & 16 & 16.0 \\
\hline & Study Area & 3 & 35 & 11.7 \\
\hline
\end{tabular}




\section{Ring-necked Pheasants}

Pheasant crowing count surveys were conducted in the Sarpy Creek study area during March and April. Similar surveys in the surrounding drainages were also conducted. These routes are shown in Figure 9 . There were an average of 13.3 calls per two minute stop in the Sarpy Creek area (Table 13). This compares with an average of 4.7 in the surrounding areas. The area of highest pheasant numbers, lower Sarpy Creek with 27.7 calls per stop, has been regularly surveyed by the Montana Department of Fish and Game since 1967. Its average for the previous 7 years was 23.4 calls per stop (Wallestad 1974).

Table 13. Ring-necked pheasant crowing count survey data.

\begin{tabular}{|c|c|c|c|}
\hline Route & Length & Number of $\mathrm{Cal}$ is & Calls/Stop \\
\hline $\begin{array}{l}\text { *Lower Sarpy Creek } \\
\text { *Upper Sarpy Creek } \\
\text { Lower Tullock Creek } \\
\text { Upper Tul lock Creek } \\
\text { Armells Creek } \\
\text { Yellowstone Ri ver } \\
\text { *Beaver Creek } \\
\text { *East Bear Creek } \\
\text { *E. F. Sarpy Creek } \\
\text { Reservation Creek }\end{array}$ & $\begin{array}{r}20 \\
16 \\
15 \\
14 \\
21 \\
23 \\
10 \\
5 \\
7 \\
16\end{array}$ & $\begin{array}{r}554 \\
127 \\
70 \\
149 \\
56 \\
87 \\
18 \\
49 \\
24 \\
59\end{array}$ & $\begin{array}{r}27.7 \\
7.9 \\
4.7 \\
10.7 \\
2.7 \\
3.8 \\
1.8 \\
9.8 \\
3.4 \\
3.7\end{array}$ \\
\hline *Sarpy Study Area & 58 & 772 & 13.3 \\
\hline Surrounding Area & 89 & 421 & 4.7 \\
\hline Total & 147 & 1193 & 8.1 \\
\hline
\end{tabular}

White-tailed Deer

White-tailed deer have been observed in the Sarpy Creek bottom. Some ranchers have indicated that whitetail numbers are increasing; however, not enough observations were made during the last year to permit any data analys is.

\section{Merriam's Turkey}

In 1957, 2 tom and 15 hen turkeys were released in the Sarpy Creek area. During this past winter, 43 turkeys, 8 of which were toms, were reported on the East Fork Sarpy Creek (Figure 9). Five toms and eight hens were seen in April on the ridge south of East Fork and one tom was seen north of East Fork. Wallestad (1974) reports a long-term average of 7.2 young per brood for turkeys in southeastern Montana. 


\section{QUESTIONNAIRE RESULTS}

A questionnaire was distributed to the ranchers and farm people who live or own land within the Sarpy Creek study area. Each returnee is generally limited in expertise to his or her own lands and observations of wild ife obtained in conjunction with normal daily activities. Although wildlife observations were not their primary interest, it is felt by the author that the results of this questionnaire fairly represent the consensus view of farmers and ranchers in the area, and are a representative barometer of the general wildlife trends. Discussion of the questionnaire is handled in two sections, "Possible Effects of Development" and "Wildlife History." A total of 268 questionnaires was handed out to 120 family units, and 63 , representing 40 family units, were returned. This amounts to a 33.3 percent return for family units and 23.5 percent return for individuals.

\section{Possible Effects of Development}

The first question was, "Do you feel coal development will adversely affect wildlife?" Seventy-eight percent responded "yes," while only 17 percent said "no" (Figure 10). Five percent were undecided or gave no response. Those who said yes had some of the following comments: "More people will mean more poaching... with more people comes more activity and greater hunting pressure, legal and otherwise... the mine itself won't, it's the people that come with it... the railroad and its 5 -foot fence, noise from equipment and all the people...wildlife can't survive on huge mounds of nonvegetated land... it already has... a heavy influx of people and activity scares off wildlife as well as kills many of the animals and birds cars, poachers, etc.... the people who work at the mines do more damage than any equipment... When 1 and and plants are disturbed, animals and birds have to go into foreign territory for food and cover away from noise and people. They encroach on other wildlife territory, putting additional need on that land for food and forage." Those who said no had some of the following comments: "Not if proper reclamation is done...wildlife populations have always fluctuated up and down anyway.... if the wildlife balance is maintained, surrounding cover and reclamation should retain sufficient habitat...not in a large area, it might right where the coal is being mined...not unless it spreads and takes in a great deal of 1 and... it is and always has been we humans that destroy ourselves and everything else..."

From these comments it is obvious that the residents as a whole feel the wildlife populations will suffer mainly from the increased number of people in the area and that the mining itself is secondary.

The second question was, "What level of coal development do you favor?" Four choices were included: high, moderate, low and none (Figure 11). Sixty-five percent of those responding favored low or no coal development and 27 percent favored moderate development. Not one person indicated a preference for high development. Eight percent made no response. Some comments made were: "Only if there must be mining to support the energy demand, just enough for Montana...l let's go slow and see what changes occur... there should be more regulation, fewer companies and not so many places torn up...the coal is not really needed that much and they are probably going to send it to another country anyway... when it is gone, there is no 


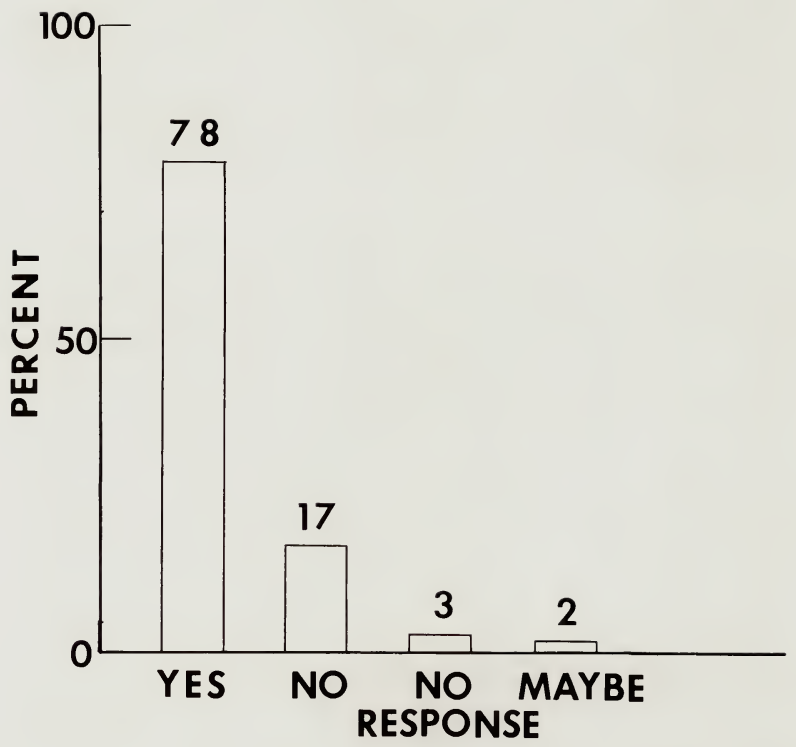

Figure 10. "Do you feel coal development will adversely affect wildlife?" 


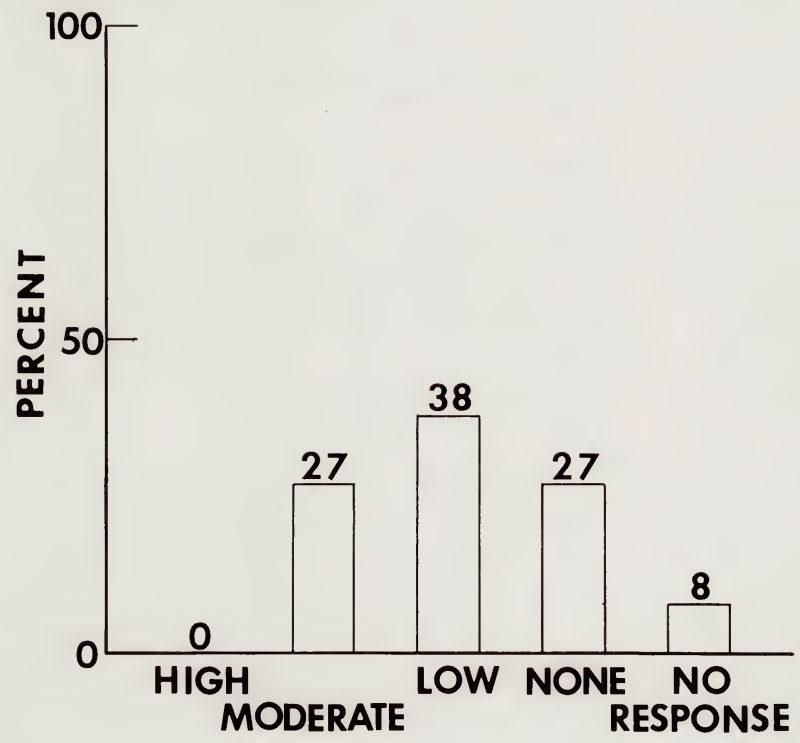

Figure 11. "What level of coal development do you favor?" 
more, what about generations to come?... I feel we should only mine what is absolutely necessary to prevent disaster. It should be saved for a possible greater and more important future use... I don't believe the shortage is as critical as they claim... mine coal for our immediate needs and ship it to where it is needed for power. Do not burn it in Montana... we don't need transmission lines and gasification plants cluttering our Big Sky... whatever it takes to help the country, but not more than necessary so iarge companies can't just use it to make large profits..."

Analysis of this question shows that the people of the area are willing to sacrifice some of their land to strip mining, but only for bona fide national and state needs.

Question three was, "Do you feel the reclamation of strip-mined land is possible in your area?" Forty-four percent thought that reclamation was indeed possible. Thirty-seven percent said no, while sixteen percent were undecided (Figure 12). Some comments of those who believe reclamation is possible were: "If properly contoured, Mother Nature will heal the scars... properly supervised... if they stockpile the topsoil, don't leave the steep slopes and replace the topsoil all over to a depth of 6 inches or more... highly improbable that there will be a return to premining days for man or wildlife... if the state will enforce all strip mining and reclamation laws... if the coal companies are forced to, if not they won't bother...much of the land over the coal is scrub pine and sand rock. I think much will be better after it is reclaimed... there is no question about it being suitable for reclamation... anything is possible with enough money..."

Some comments from those who believe that reclamation is not possible were: "There is not enough topsoil and too little water... it will take too long and much money to get the land back to a usable state...the soil is too sandy and erodes too badly... the soil is shallow and some of those shale hills won't grow anything for years, as any gravel pit will prove... there can never be the same amount and quality of trees and undercover that is being destroyed...no one has a right to form a Sahara or worse... the aquifer is disrupted and this may be the greatest damage that is not reclaimed... aesthetically the land can never be the same... if you don't have water, you don't have anything... they will be able to level and grade the spoil banks but man cannot do in a few years what it took nature thousands to do...there is no way it can be made as productive as it was before... thin topsoi $i$, low rainfall, variance in backfil1, and questionable groundwater all make it

The nearly even division of opinion on this subject reflects the small amount of factual information available. No one knows if reclamation is possible or not. What is reclamation? The renewed growth of pine trees, various shrubs and native grasses or is it Russian thistles, alfalfa, sweet clover and introduced grasses with no trees or shrubs?

The fourth question was, "Do you al low hunting on your land?" This question is a barometer of the degree of frustration the ranchers and farmers feel toward coal development and the influx of people as well as 


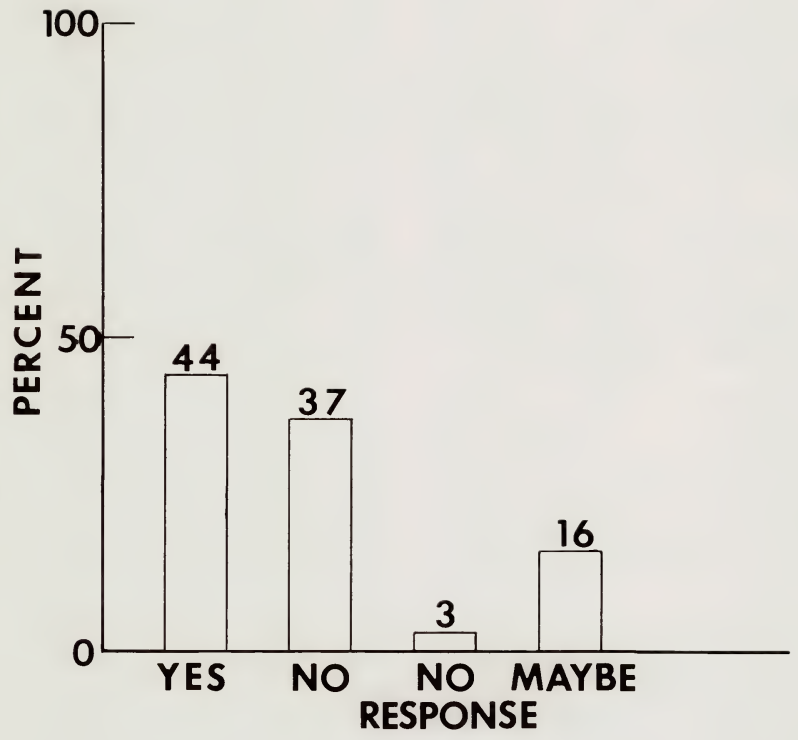

Figure 12. "Do you feel reclamation of strip-mined land is possible in your area?" 
their concern for what they think (and probably rightly so) are decreasing wildlife populations. Using only one response per family unit, 65 percent indicated they either allowe 1 no hunting or hunting with some limitations (Figure 13). Thirty-five percent allow unrestricted hunting. Some comments were: "No vehicles...no alcohol and no driving in fields... only those who have hunted here before...have until this year, now there is nothing left to hunt... too many hunters see game and begin shooting regardless of what else they might hit... by permission only.... people have no respect for landowners' rights...there is very little wild ife left in this area...not since Montana Power's influx of people pollution...no bird hunting... what game is there we want left there...too many hunters have no respect for the land, the wildlife or the landowner."

Question number five was, "What do you feel is the greatest threat to wildlife in your area?" As expected, a large variety of answers was given for this question. People in general received the most blame, gathering 37 percent of the responses (Figure 14). Predators (coyotes, foxes, skunks, etc.) were blamed in 29 percent of the responses, followed by hunters and hunting regulations with 19 percent. Poachers were specifically mentioned by 8 percent and poor weather and loss of habitat had 4 and 3 percent, respectively. Even high meat prices were blamed by one individual.

Question six, a follow-up to number five, was, "What do you think the Department of Fish and Game can do to remedy this situation?" It provided some serious as well as enlightening suggestions. "Nothing- too many drunks with guns...hire more wardens... have shorter seasons and provide coyote control...get ranchers to leave corners and protect habitat by fencing, develop more open water sources... oppose any gasification plants, coal field generation plants, especially in the best deer and turkey habitat... have more concern for personal property. Cooperate with landowners and do not assume all rights to determine permitting hunters to run at large on private or leased lands. Producing game for others to kill is competitive to livestock producers' livelihood. We don't want pay, only consideration, good will and respect...get rid of coyotes, foxes and skunks and close this area to hunting (at least one deer only) for a great number of years...probably nothing... restrict the population increase to urban areas and establish stricter game laws... increase the number of game wardens in the mining and surrounding area... reinstate the use of 1080 ...strict laws concerning coal mining, ship the coal and pollution some place else and make Montana Power Company understand that this is our state too...help in fighting construction of additional mine-mouth generating plants... inform incoming people of their responsibility in protecting as much wildlife as possible...no more roads, no rampaging on snowmobiles, no hunting for a few years and reclamation of all lands...eliminate open seasons on female deer....better public relations between the Fish and Game Department, public, ranchers and farmers...patrol the area more for poachers... lobby against policies and projects which will harm wildlife populations. Issue stiff penalties against poachers and give poachers bad publicity in papers, TV and radio... let the ranchers take care of coyotes that bother them...limit the number of licenses sold on all wildlife...control coyotes, raccoons and skunks...enforce present laws to the limit, punish poachers and trespassers and do not allow pollution of streams and dams." 


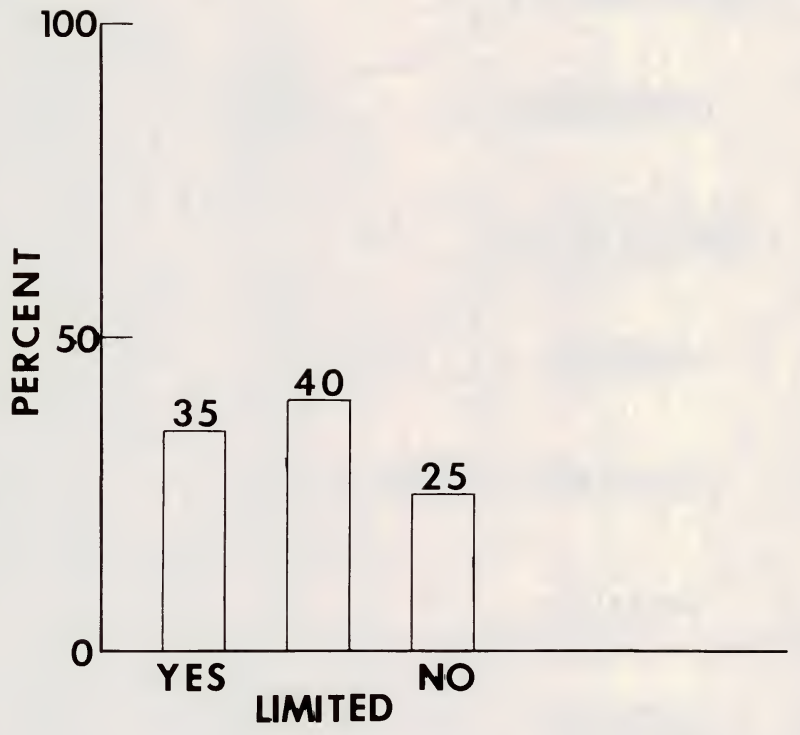

Figure 13. "Do you allow hunting on your land?" 


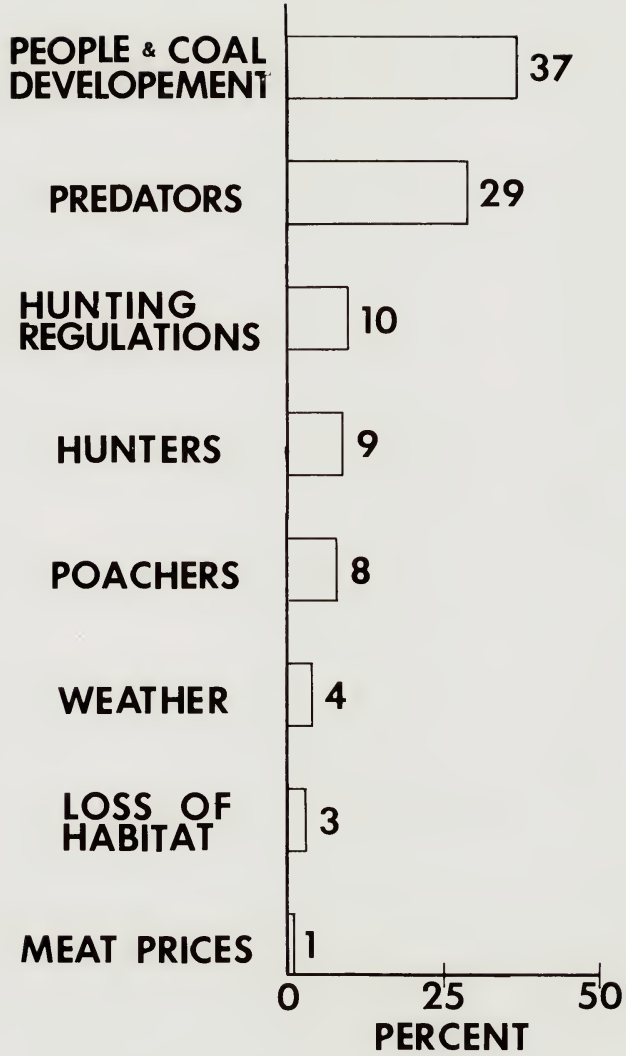

Figure 14. "What do you feel is the greatest threat to wildiife in your area?" 


\section{Wildlife History}

The second portion of the questionnaire called on the residents to make a subjective assessment of population levels for selected wildlife species, including mule deer, white-tailed deer, pronghorn antelope, sage grouse, sharp-tailed grouse, pheasants, mice, rabbits and coyotes (Canis latrans). The ratings ranged from excellent or high levels to terrible or very low levels and were assigned a number on a 1 to $5 \mathrm{scale}$. All responses were arbitrarily separated into two groups. Those who responded to the time frames earlier than 1931 were called "old timers" and those responding only in later years were called "newcomers." Results are included in Appendix Table 17.

\section{Mule Deer}

Mule deer populations seem to have reached a low during the 1920's and a peak in the 1950's (Figure 15). This corresponds with population fluctuations of the Missouri Breaks deer reported by Mackie (1970). A relatively stable population existed during the latter portion of the 1960's. The residents report a very sharp drop occurring between 1972 and 1973 . They expect a slight increase in levels in 1975 but predict generally lower populations, approaching the low levels recorded in the 20 's, extending into the 1980's. 0ld timers and newcomers generally agreed about this.

Mule deer harvest statistics (Figure 16) indicate a peak occurred in the late $50^{\prime} s$ and early $60^{\prime}$ 's in southeastern Montana, followed by a low which bottomed out in 1967. Statistics for Hunting Districts 720 and 722, which include Sarpy Creek, reflect the climb from 1967 and a possible peak in 1971. The area is also included in old Hunting District 72 which gives information back to 1956, the first year for which such statistics are available. Fawn per 100 adult ratios from 1960 to 1973 are shown in Figure 17. This shows that production levels were lowest in 1961 and 1965 and highest in the early 1970's for southeastern Montana. They show peak production in the period of 1968 to 1970 in the area including Sarpy Creek, followed by quite drastic reductions, especially in District 722 , the area in which the Colstrip facilities are located. Production in the Sarpy Creek area appears to be above its surrounding environs.

White-tailed Deer

White-tailed deer were generally absent from the area in the early years of settlement. Since 1941 whitetails have been extending their range over much of eastern Montana (Mussehl and Howell 1971). This pattern is reflected in Figure 18 with a peak reached in the 1950's. Residents report a slight decline from that time, probably continuing on into the future. 01d timers and newcomers disagreed on the change from 1971 to 1972 and in the future, 1975.

Harvest statistics (Figure 19) show almost yearly fluctuations of large magnitude with numbers generally up over all of Region 7 . 01d Hunting District 72 showed lows in 1956, 1959, 1962 and a prolonged low stretching from 1967 to 1969. Peak years were 1960 and 1966 with an upward trend established since 1970. In the immediate areas of Sarpy Creek, 722 peaked in 


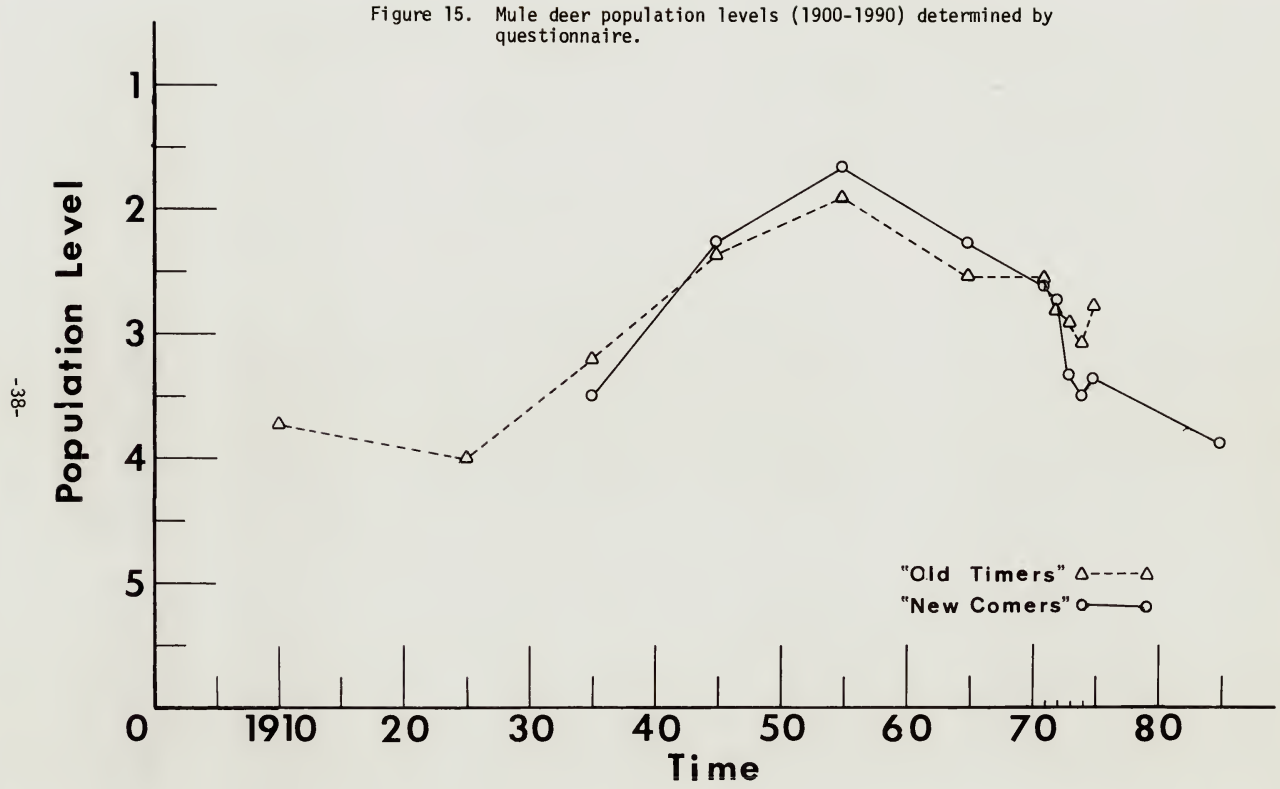


Figure 16. Mule deer harvest statistics.

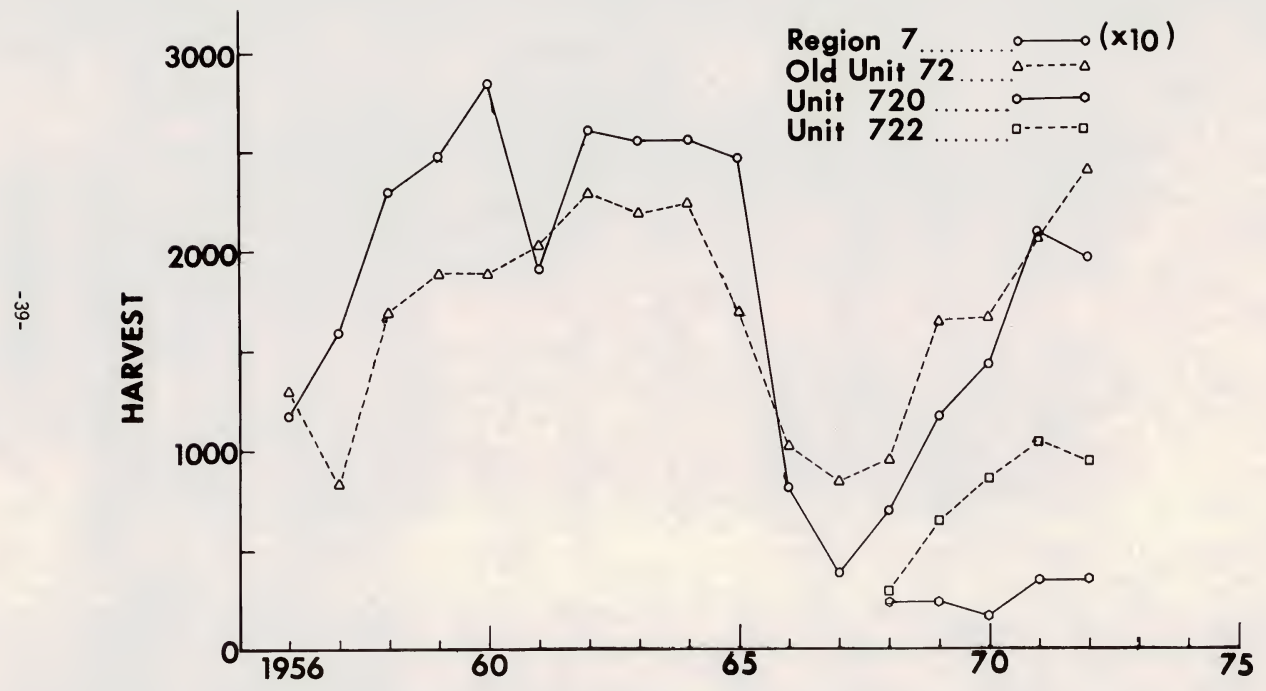


Figure 17. Mule deer and white-tailed deer production statistics.

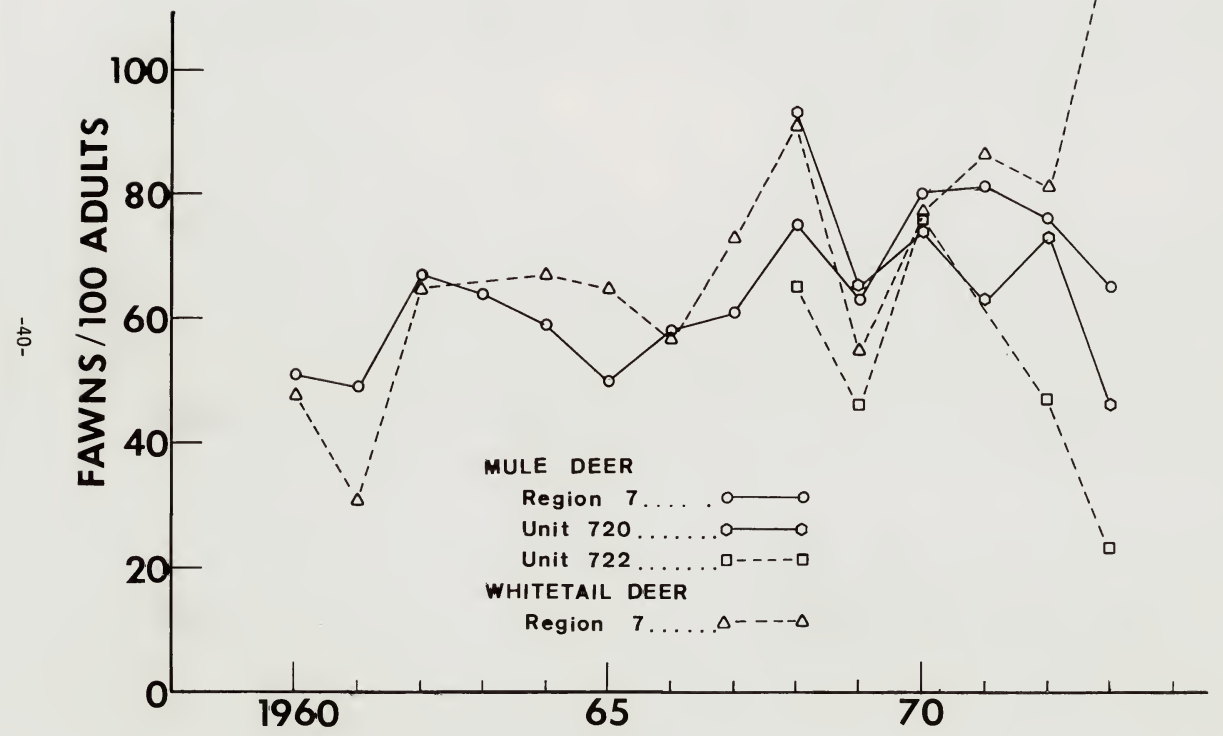


Figure 16. Mule deer harvest statistics.

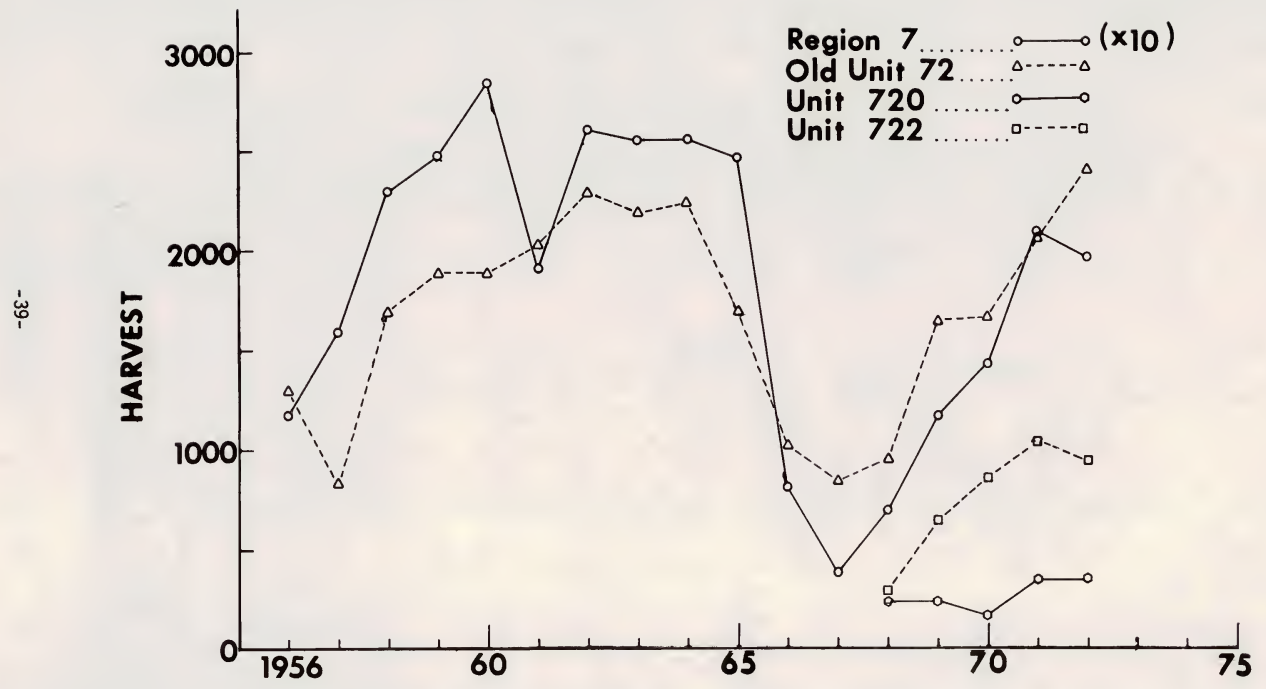


Figure 17. Mule deer and white-tailed deer production statistics.

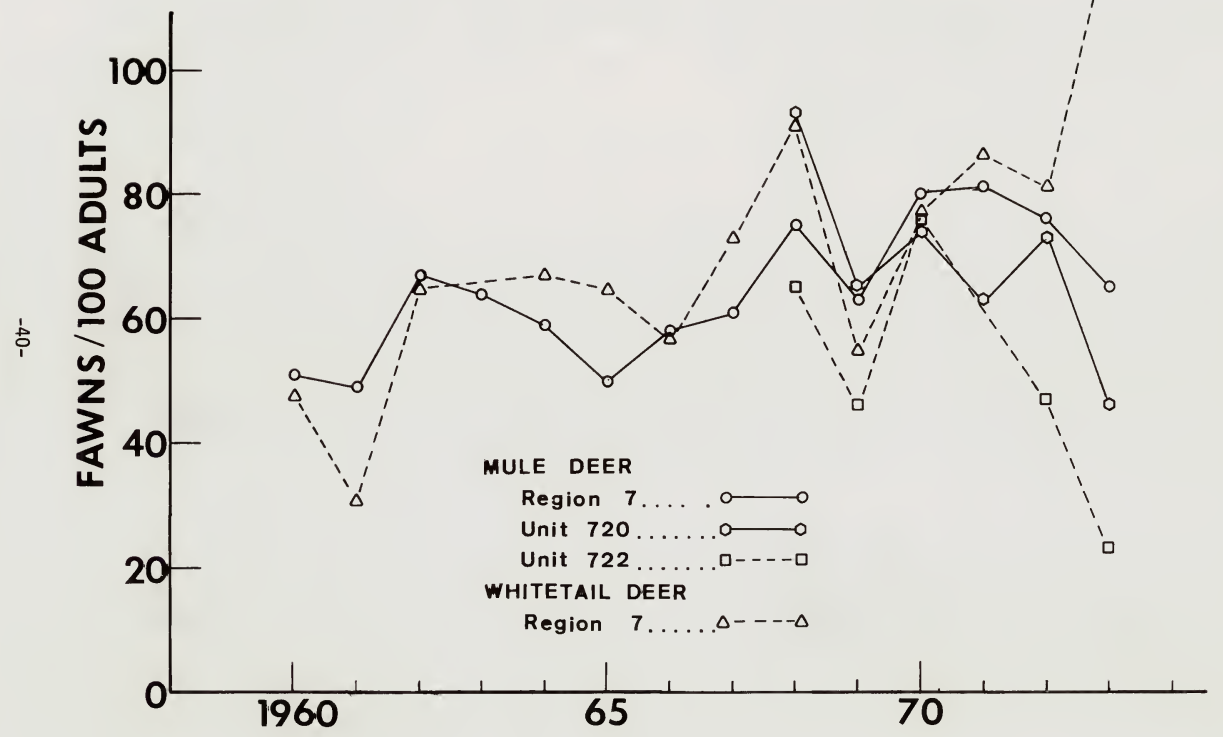




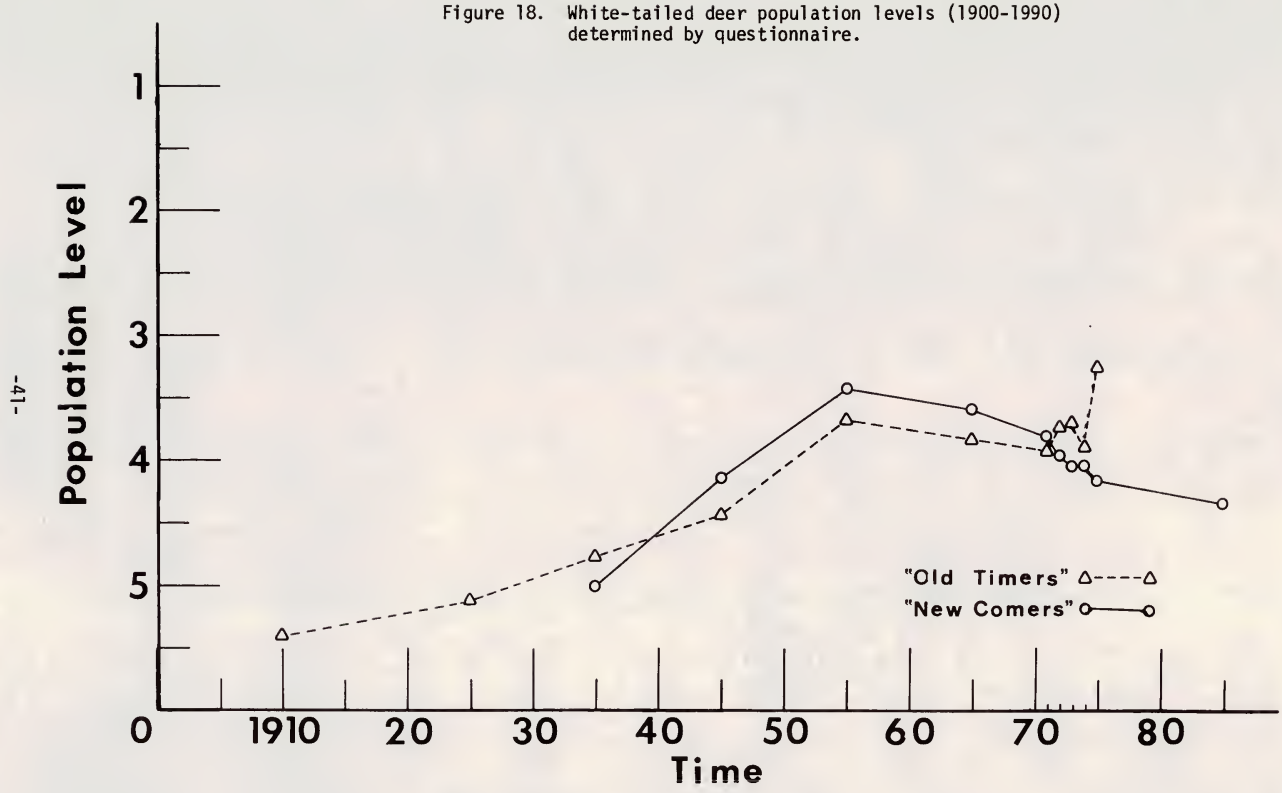


Figure 19. White-tailed deer harvest statistics.

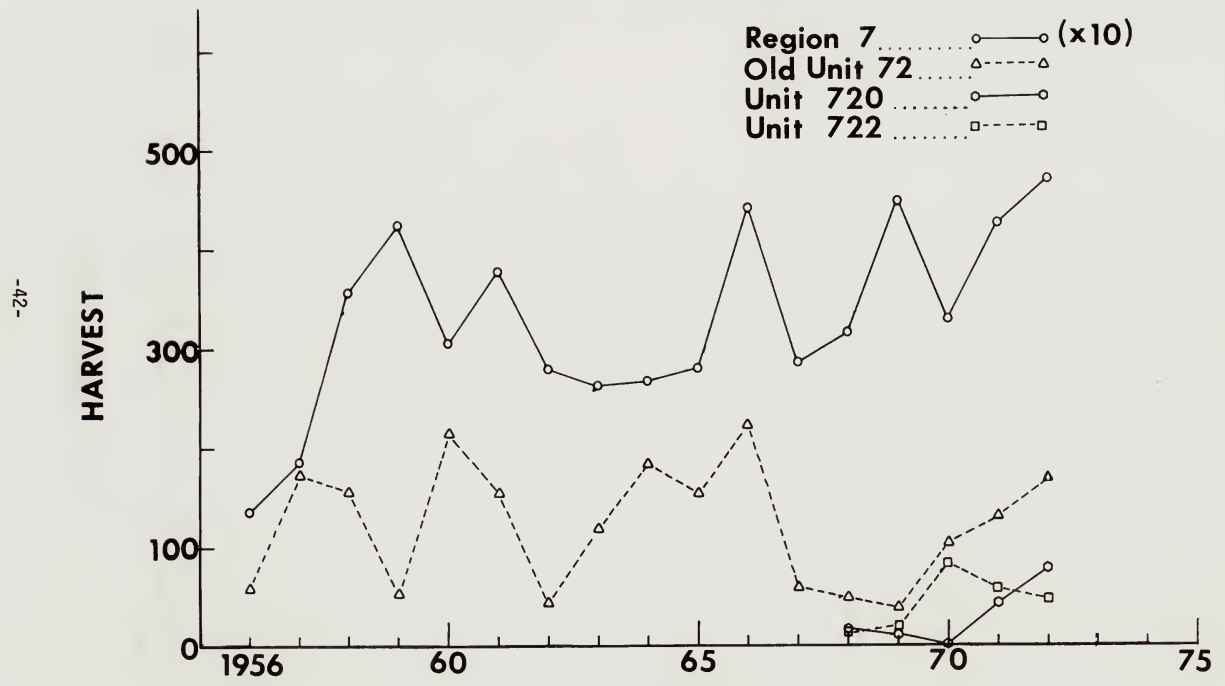




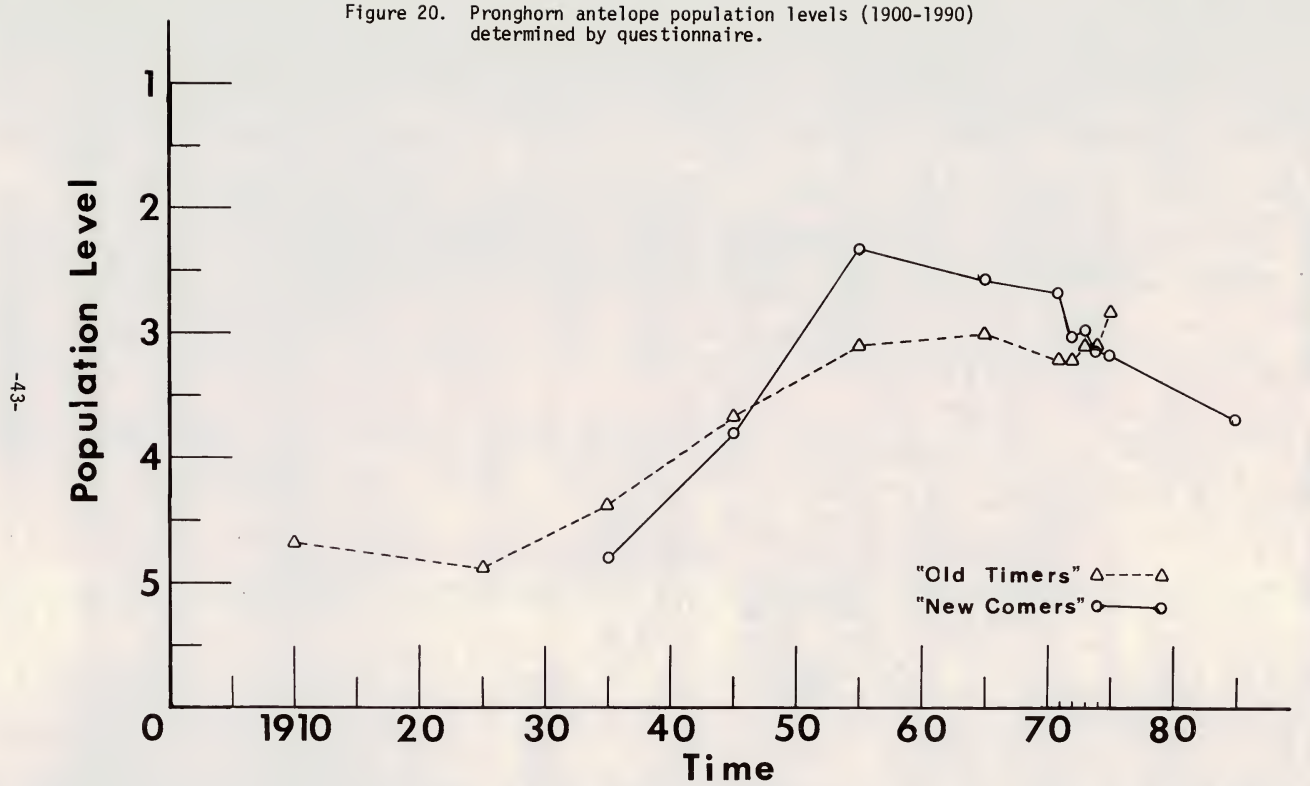


Figure 21. Antelope harvest statistics.

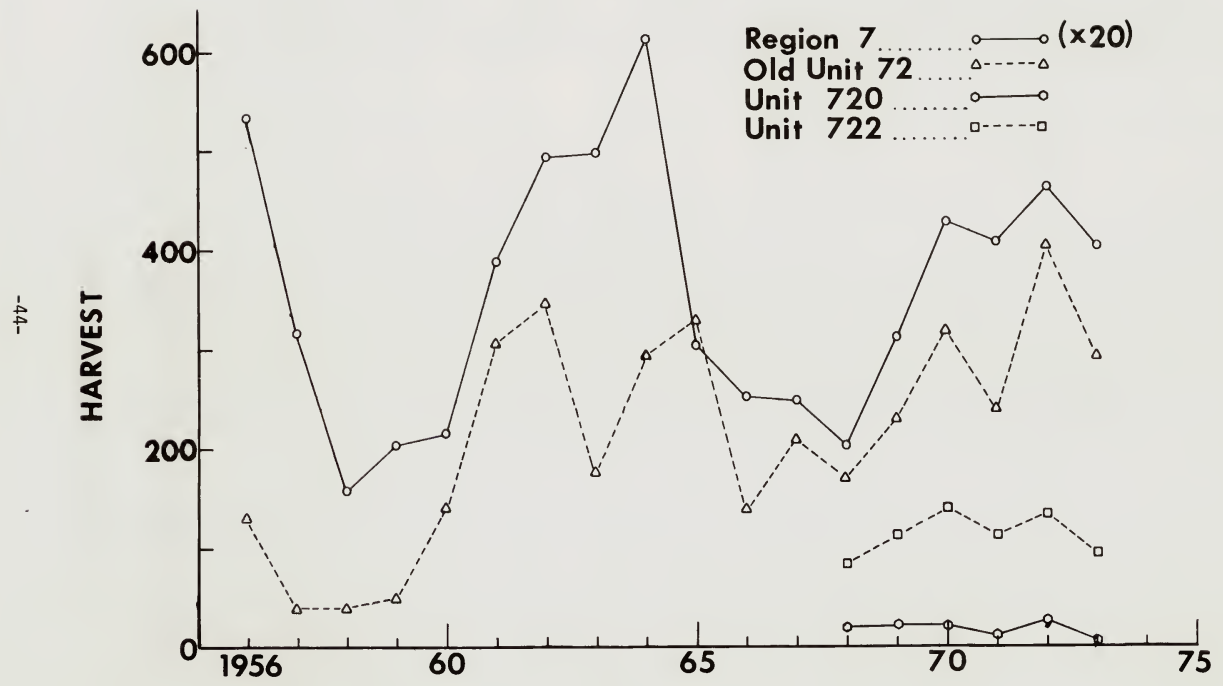


1970 and has declined since, while 720 has shown the exact opposite trend. Production of whitetails in southeastern Montana (Figure 17) indicates a steadily increasing population, with lows occurring in 1961, 1966 and 1969. Peak production years were 1968 and 1973.

\section{Pronghorn Antelope}

Figure 20 shows that antelope numbers were very low to around 1940. Peak numbers occurred either in the $50^{\prime} \mathrm{s}$ (newcomers' opinion) or in the 60 's (old timers' opinion). Mussehl and Howell (1971) report that antelope were abundant in Montana as late as 1896, dwindling during the period of settlement and increasing from around 11,000 in 1937 to 75,000 in 1965 .

Harvest statistics reported since 1956 (Figure 21) indicate a low in the late 50's and again from 1966 to 1968. Peak harvests occurred in 1956, 1964 and 1972. 01d area 72 follows the same trend. Hunting Districts 720 and 722 have maintained relatively stable, if low, harvests. Production statistics gathered every 3 years since 1963 are shown for Hunting Districts 720 and 722 in Table 14. Fawns per 100 does was highest in 1963 and lowest in 1972 in both areas. Fawns per 100 adults follow the same downward trend.

Table 14. Historical antelope population characteristics in the Sarpy Creek vicinity. I/

\begin{tabular}{|c|c|c|c|c|c|c|}
\hline Year & $\frac{\text { Fawns } / 100}{720}$ & $\begin{array}{l}\text { Females } \\
722 \\
\end{array}$ & $\begin{array}{l}\text { Fawns/100 } \\
720\end{array}$ & $\begin{array}{l}\text { Adults } \\
722 \\
\end{array}$ & $\begin{array}{l}\text { Males/100 } \\
720\end{array}$ & $\begin{array}{l}\text { Females } \\
722 \\
\end{array}$ \\
\hline 1963 & 75 & 103 & 60 & 75 & 25 & 38 \\
\hline 1966 & 54 & 85 & 43 & 67 & 26 & 28 \\
\hline 1969 & 79 & 86 & 56 & 65 & 39 & 32 \\
\hline 1972 & 40 & 65 & 31 & 52 & 29 & 24 \\
\hline Average & 62 & 85 & 48 & 65 & 30 & 31 \\
\hline
\end{tabular}

1/ Taken from Wentland (1974).

Sage Grouse

The old timers report very high population numbers of sage grouse in the early 1900's (Figure 22). Populations declined continuously to the 1970 's. Since then the old timers say the population has stabilized, while newcomers indicate an increased reduction rate after 1971. Apparently by the mid-1930's an estimated 50 percent decrease had occurred in the bird's original habitat (Mussehl and Howell 1971). 


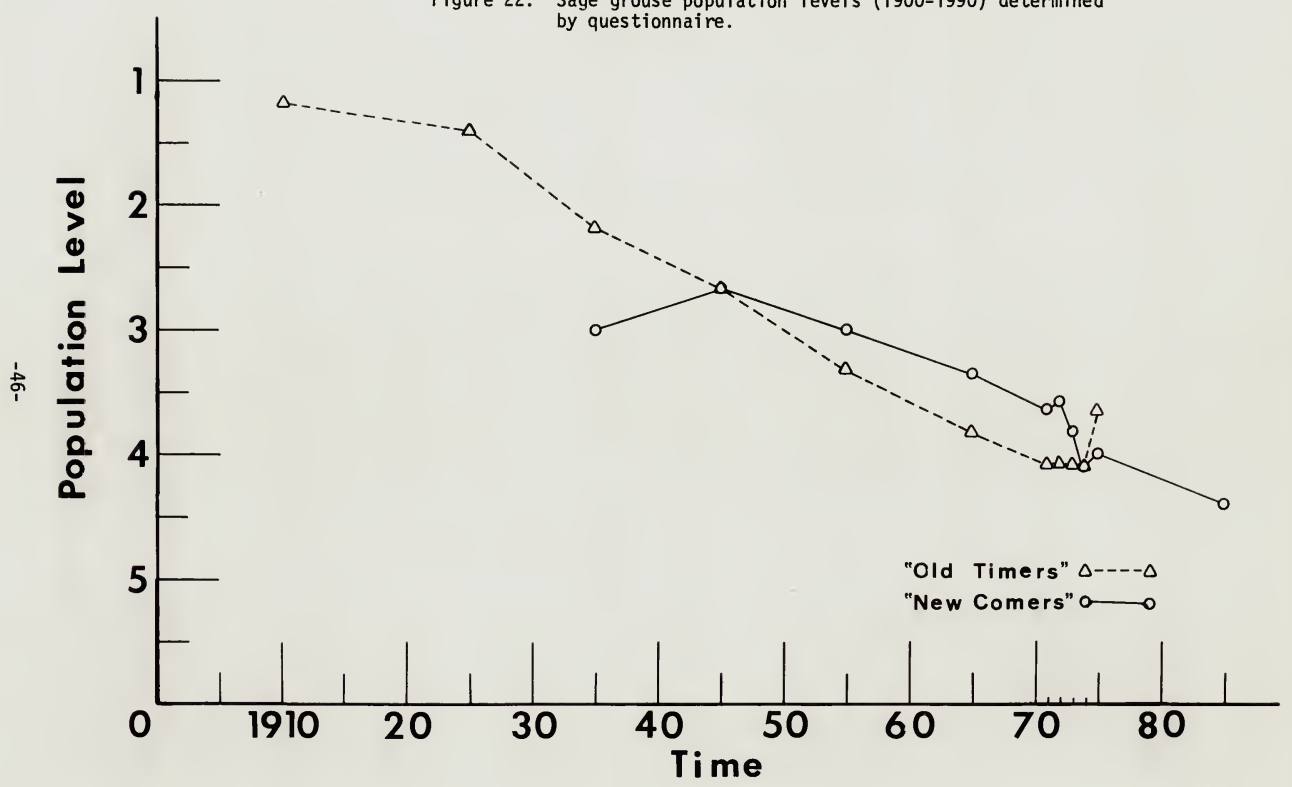


Production of sage grouse in southeastern Montana has ranged from 4.4 young per brood to 5.8 young per brood with an average of 4.9 since 1963 (Wallestad 1974).

Sharp-tailed Grouse

Sharptail numbers were also very high in the early days of settlement (Figure 23). They have apparently remained stable since the early 1940's with old timers reporting a slight decline and recovery while newcomers thought an increase followed by a slight decline occurred up to the late $1960^{\prime}$ s. Since 1971 sharptail numbers have apparently declined at a drastic rate.

Young per brood has ranged from 5.8 to 8.8 , with an average of 6.7 in southeastern Montana (Wallestad 1974).

Ring-necked Pheasant

Figure 24 shows a dramatic increase in pheasant populations between the 1920's and 30's, reaching a peak in the 1950 's or early 60 's. Sharp declines apparently occurred between 1971 and 1973. Future populations will continue to dwindle in the consensus of opinion of the residents. Musseh1 and Howe11 (1971) report that pheasants were abundant in some portions of the state, and that the Yellowstone River valley was a source for transplanting birds in the 1940's.

Young per brood ranged from 5.2 to 8.5 , with a 10-year average of 6.8 in southeastern Montana (Wallestad 1974).

Rabbits

The questionnaire returns indicate that rabbit numbers peaked in the 1920 's with a secondary peak occurring in the 1950's (Figure 25). The populations have apparently declined since then. Newcomers indicate a population increase from 1973 to 1974 with both groups predicting future population increases.

Mice

Populations of mice have remained stable in the moderate-to-high range (Figure 26). Newcomers indicate a population increase since 1971, while the old timers believe mice populations have decreased.

\section{Coyotes}

Coyote populations were apparently stable in the early years of settlement, ranging at the upper moderate-to-high level. With the advent of large scale poisoning programs, population levels decreased, reaching bottom in the 1950's (Figure 27). Population levels began to increase as coyotes, known to be very intelligent, apparently were learning to avoid the poisons. When 1080 and other poisons were banned in the early 1970's, the coyote population, already increasing, skyrocketed. Both groups apparently believe that the population peak has been reached, as they predicted lower levels for 1975 and the $1980^{\prime} \mathrm{s}$. 


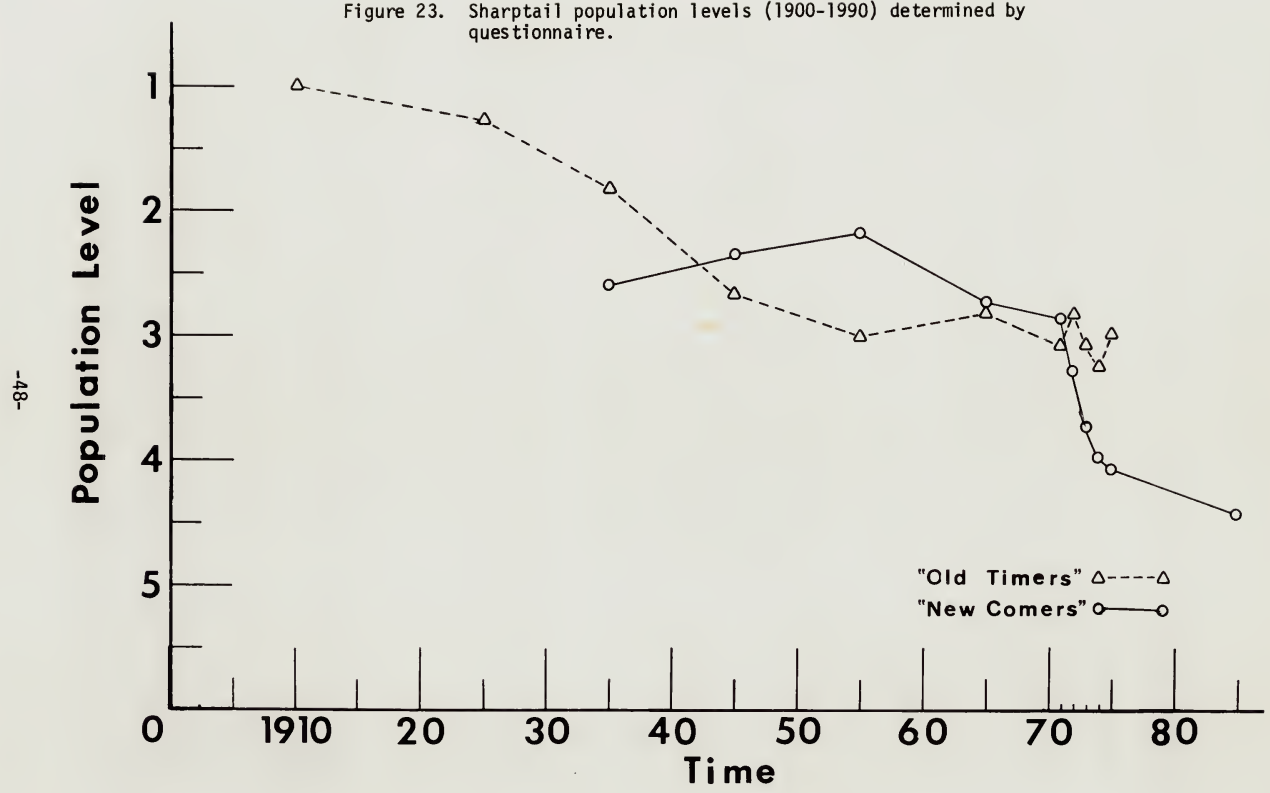




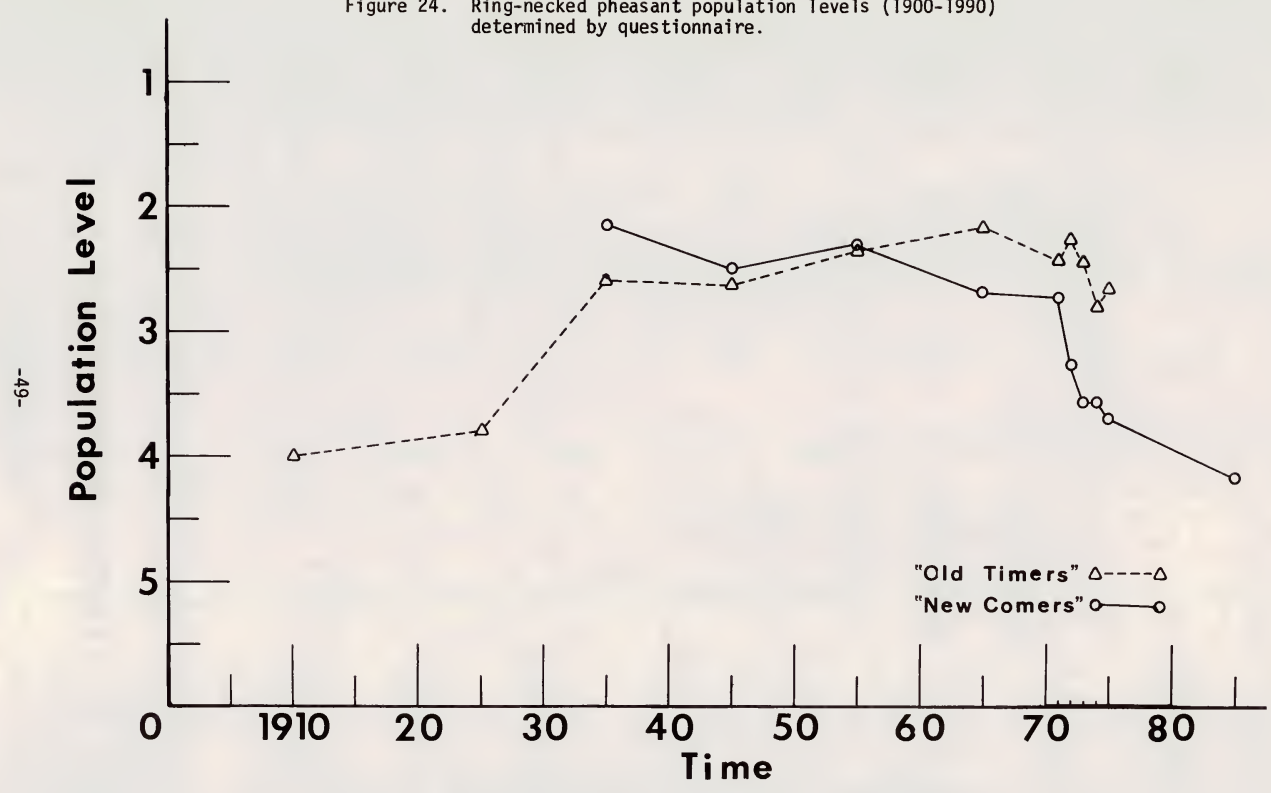




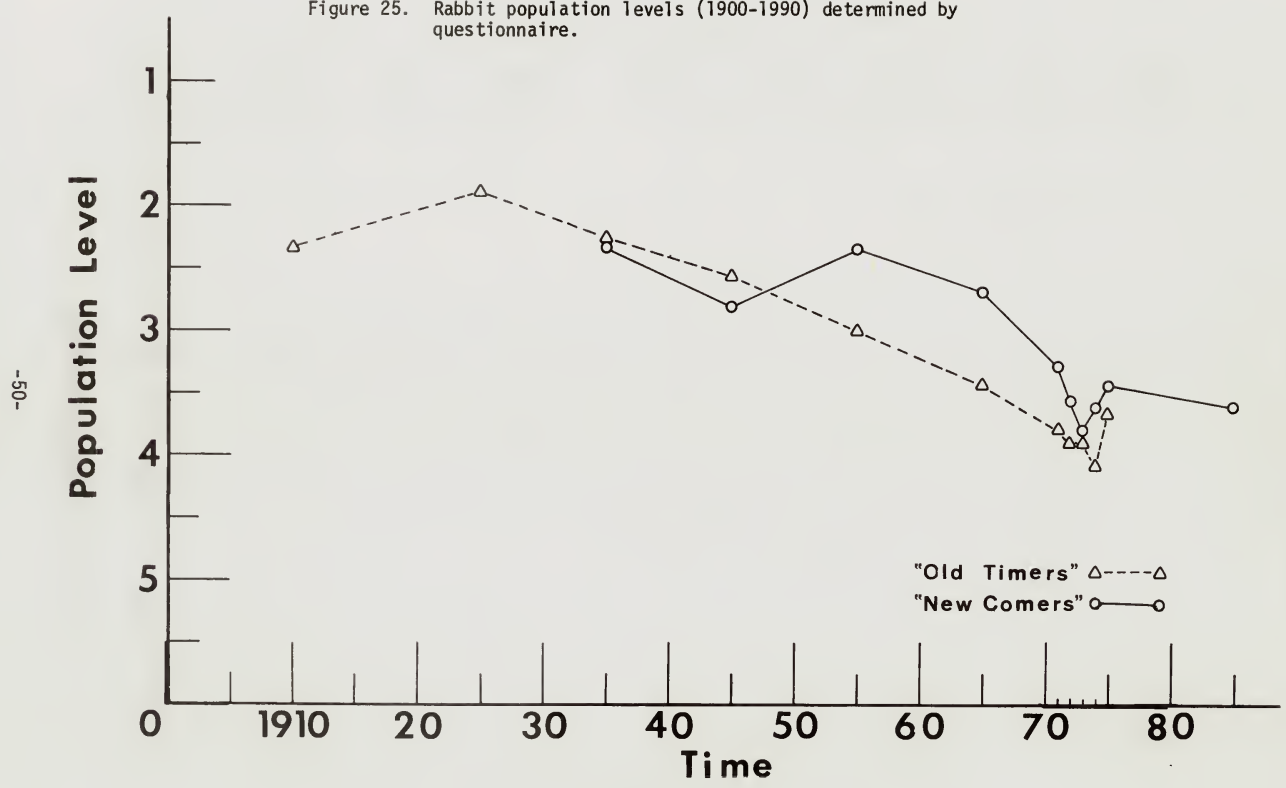




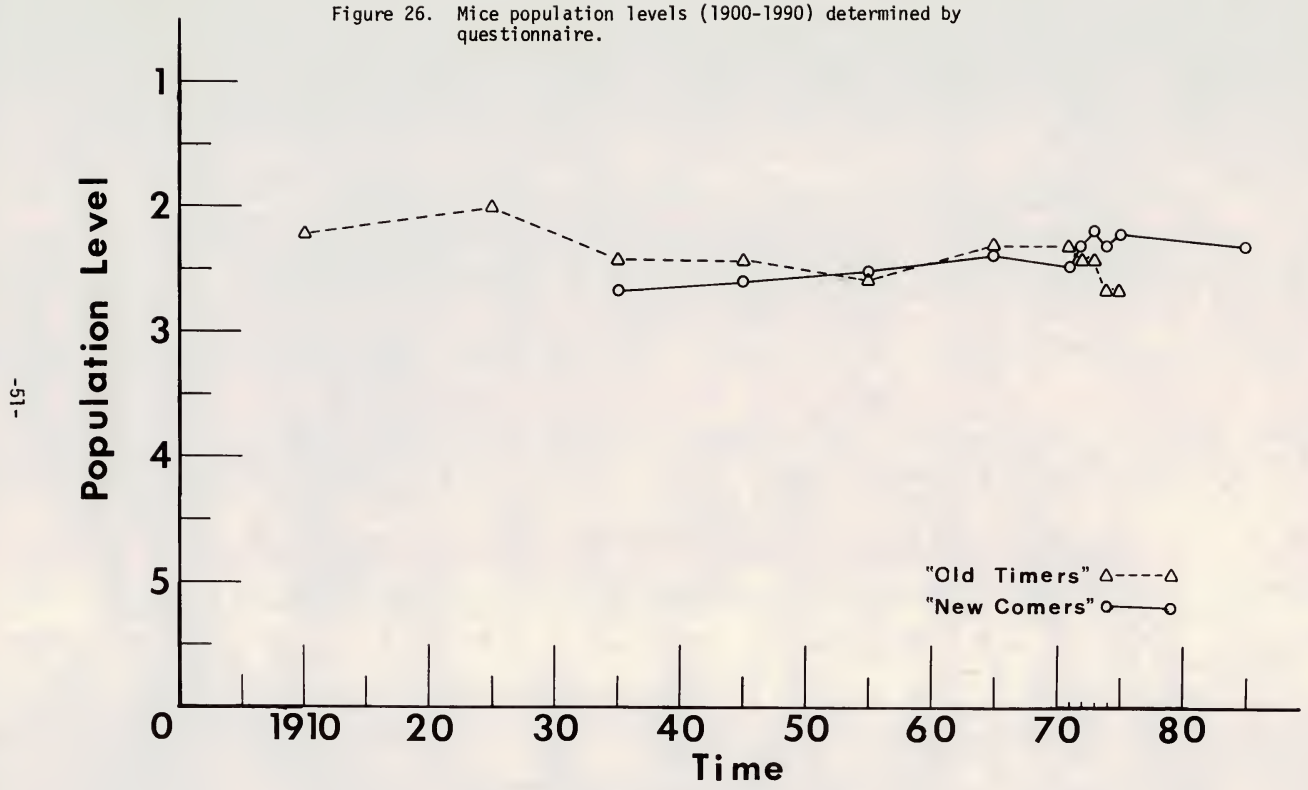




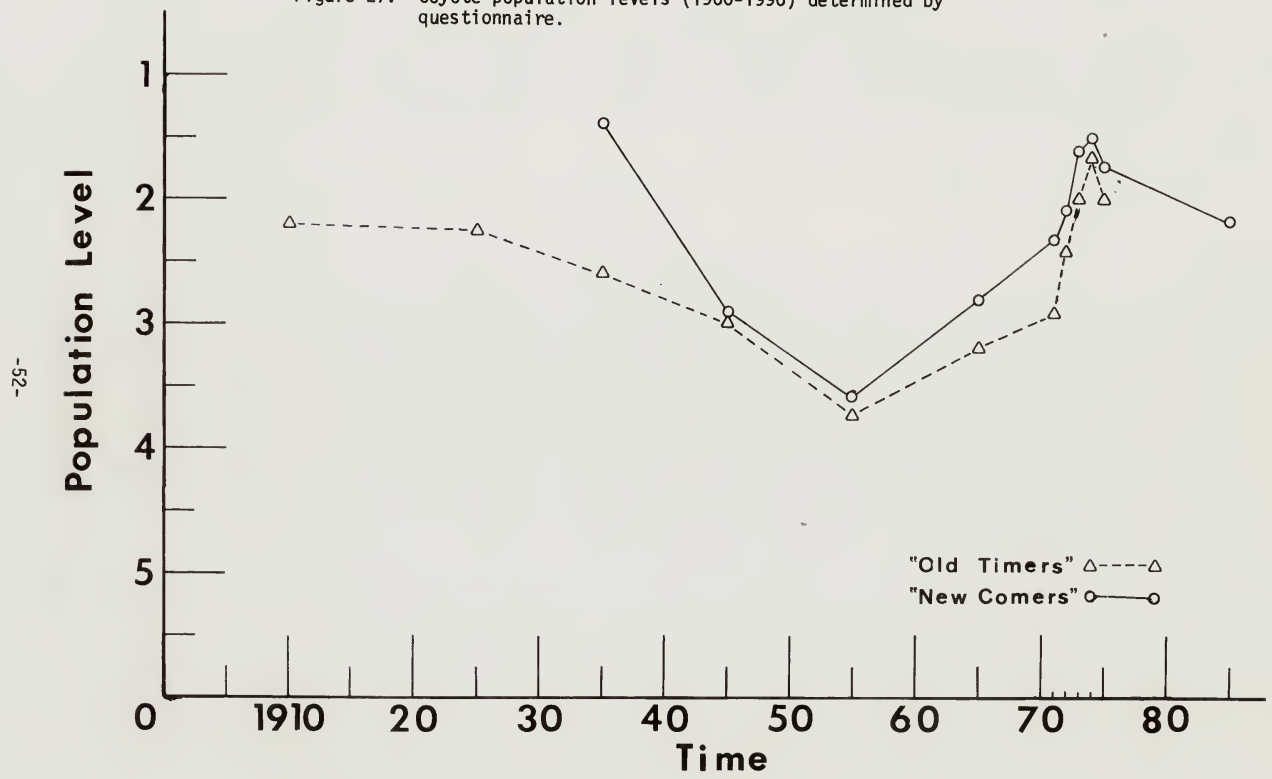
Figure 27. Coyote population levels (1900-1990) determined by
questionnaire. 
It is interesting to note that the old timers believe there are more coyotes now than in the early days (1900-1920) and the newcomers feel that there were more coyotes in the 1930's than at present. These discrepancies can be accounted for because some of the individuals allow emotionalism to cloud their assessment of true population levels. It is for this reason that all of the population levels reported here are not considered as exact, but only as general approximations.

\section{SUMMARY}

During the first year of the Sarpy Basin Wildlife Ecology Study, some important baseline data were gathered. General climatic conditions were outlined. Six general soil associations were mapped and five vegetation types with a total of fourteen subtypes were qualitatively described. Distribution, seasonal use of soil associations, vegetational types, slopes and exposures, and population characteristics were discussed for the important game species in the area. A questionnaire distributed to residents of the area revealed their opinions on several coal development related subjects, as well as their solutions to some of the problems associated with the effects of coal development on wildlife. A brief history of selected wildlife species was presented with information gathered from area residents and Montana Fish and Game Department records.

A few observations and tentative conclusions resulting from the first year of study follow:

1. The Bainville-Midway/Thedalund-Midway soil association may be the most important concerning mule deer, pronghorn antelope and prairie grouse, especially sage grouse.

2. The ponderosa pine type and subtype appear to be most important to mule deer while the big sage-grassland type is most important to antelope.

3. Mule deer seem to utilize creek bottoms almost exclusively during the fall months. This movement to the lower elevations could be caused by xeric conditions prevalent on the ridges and plateaus after a hot and dry summer.

4. The Sarpy Creek area appears to have a healthy mule deer population at least comparable to most populations in other portions of eastern Montana and much better than some.

5. Antelope populations are poor, compared to other areas in southeastern Montana, probably due to a lack of the proper habitat.

6. The area appears to have excellent potential for sharptail populations and very little for sage grouse.

7. Pheasants seem to occur primarily in the lower half of the drainage.

8. The residents overwhelmingly feel that coal development, primarily through increased human population levels, will adversely affect wildlife 
populations. Nearly two-thirds prefer low or no coal development, and in any case, for export only.

Recommendations most often mentioned to improve or maintain the lot of wildlife in the area were for more cooperation between farmers and ranchers and the Department of Fish and Game, more game wardens, stricter hunting regulations, increased control of predators (primarily coyotes), and restriction of coal development, especially mine-mouth plants.

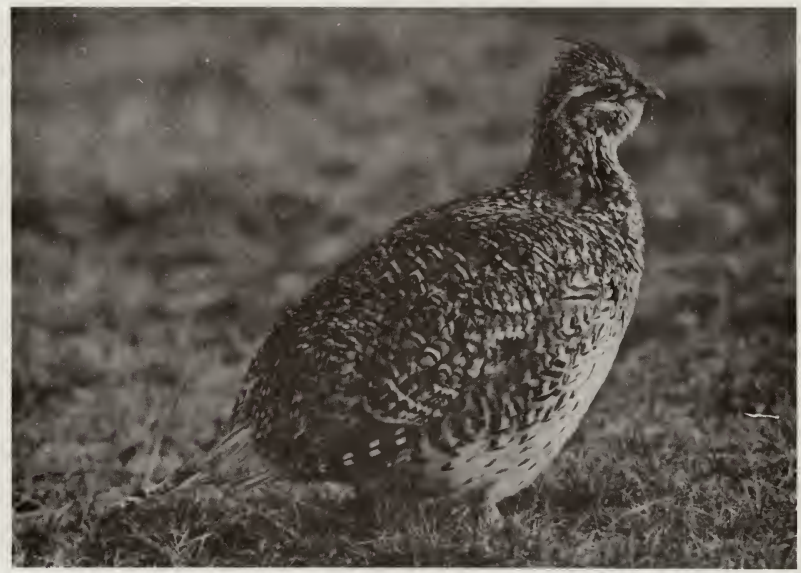




\section{Literature Cited}

Caprio, J. M. 1965. Average length of frost-free season. Coop. Ext. Service, Mont. St. College, Bozeman. Folder No. 83.

Dightman, R. A. 1972. Climate, Big Horn County. Unpublished. Big Horn County Area, Montana, Soil Survey. p. 1062-1064.

Dusek, G. L. and S. A. McCann. 1974. Bull Mountains coal field study. Mont. Dept. of Fish and Game and Consolidation Coal Co., Prog. Rept. $76 \mathrm{pp}$.

Eustace, C. D. 1974. Big game survey and inventory (deer). Job Prog. Rept. Mont. Fish and Game Dept. Unpubl. $11 \mathrm{pp}$.

Jackson, P. V. 1971. Montana rangeland resource program. Coop. Ext. Service, Mont. St. Univ., Bozeman. $56 \mathrm{pp}$.

Knapp, S. J. 1972. Range use of mule deer prior to initiation of restrotation grazing for cattle on the Fort Howes Ranger District, Custer National Forest, Montana. Mont. St. Univ., Bozeman. Unpub7. Thesis (M.S.). $50 \mathrm{pp}$.

Mackie, R. J. 1970. Range ecology and relations of mule deer, elk and cattle in the Missouri River Breaks, Montana. Wildl. Mono. No. 20. $79 \mathrm{pp}$.

Meshnick, J. C., J. H. Smith, G. G. Laverne, R. F. Peterson, D. H. Gentz and R. Smith. 1972. Big Horn County area, Montana soil survey. U. S. Dept. Agric. S.C.S. and U. S. Dept. Int. B.I.A. in coop. with Mont. Agric. Exp. Sta. Unpubl. 1086 pp.

Moshier, R. L. and A. G. Fielder. 1967. Soil survey Treasure County, Montana. U. S. Dept. Agric. S.S.C. in coop. with Mont. Agric. Exp. Sta. $173 \mathrm{pp}$.

Musseh1, T. W. and F. W. Howe11. 1971. Game management in Montana. Mont. Fish and Game Dept. 238 pp.

Wallestad, R. 1974. Upland game bird surveys and inventory. Job Prog. Rept. Unpubl. Mont. Dept. of Fish \& Game. 13 pp.

Wentland, H. 1974. Big game survey and inventory (antelope). Job Prog. Rept. Unpub1. Mont. Dept. of Fish \& Game. 18 pp. 
Appendix

Table 15. A brief description of the soils series found in the Sarpy Creek drainage.

\begin{tabular}{|c|c|c|c|c|}
\hline Series & County $1 /$ & Topography & $\begin{array}{l}\text { Surface } \\
\text { Drainage }\end{array}$ & Vegetation 21 \\
\hline Wanetta & Treasure & Level to sloping terraces & Good & Short \& mid grasses \\
\hline Hesper & Treasure & Rolling, eroded uplands & Good & $\mathrm{Ag} \mathrm{sp} ; \mathrm{Ag} \mathrm{sm;} \mathrm{Ar} \mathrm{tr}$ \\
\hline Pierre & Treasure & Rolling, eroded uplands & Good & $\mathrm{Ag} \mathrm{sp} ; \mathrm{Ag} \mathrm{sm;} \mathrm{Ar}$ tr \\
\hline Lismas & Treasure & $\begin{array}{l}\text { Rolling to hilly or strongly dissected } \\
\text { uplands }\end{array}$ & Excessive & $\begin{array}{l}\text { Ag sm; St vi; Bo gr; } \\
\text { Ar tr; Sa ve }\end{array}$ \\
\hline Flasher & Treasure & $\begin{array}{l}\text { Rolling to strongly rolling or hilly, } \\
\text { eroded uplands }\end{array}$ & Excessive & Ca lo; St vi; Or hy \\
\hline Bainville & Treasure & Crests of ridges and hills & Excessive & $\begin{array}{l}\text { Brush \& trees; short, } \\
\text { mid \& tall grasses }\end{array}$ \\
\hline Thedalund & Big Horn & Undulating to very steep hills & Medium & $\begin{array}{l}\text { Ag sm; St vi; Bo cu; } \\
\text { Ar tr }\end{array}$ \\
\hline Midway & Big Hom-Treasure & $\begin{array}{l}\text { Rolling to steep, broken, eroded } \\
\text { uplands }\end{array}$ & Excessive & $\begin{array}{l}\text { Ag sp; Ag sm; Bo gr; } \\
\text { Ar ca4; Ar tr; Rh tr } \\
\text { Gu sa; Bo cu }\end{array}$ \\
\hline Nelson & Big Horn & Undulating and rolling hills \& ridges & Medium & $\begin{array}{l}\text { Ca lo; Ag sp; Ar ca4; } \\
\text { Yu gl }\end{array}$ \\
\hline Alice & Big Hom & Moderately steep \& rolling valleys & Slow & $\begin{array}{l}\text { Ca lo; Bo cu; Bo gr; } \\
\text { An sC; Eriog; Ambro }\end{array}$ \\
\hline Wayden & Big Hom & $\begin{array}{l}\text { Sloping or rolling to very steep hills } \\
\text { \& ridges }\end{array}$ & Medium & $\begin{array}{l}\text { Ag sp; Ag sm; Gu sa; } \\
\text { Ps ar }\end{array}$ \\
\hline Regent & Big Horn & $\begin{array}{l}\text { Gently undulating to hilly ridges \& } \\
\text { plains }\end{array}$ & Slow & $\begin{array}{l}\text { Ag sm; Ag tr; Da in; } \\
\text { Fe id; Ch na }\end{array}$ \\
\hline Wibaux & Big Horn & Undulating to very steep uplands & Rapid & $\begin{array}{l}\text { Ag sp; St vi; Ar fr; } \\
\text { Gu sa; Ch na }\end{array}$ \\
\hline Spearman & Big Horn & Undulating \& rolling plains & Medium & $\begin{array}{l}\text { St vi; } \mathrm{Ag} \mathrm{sm} \text {; Ar tr; } \\
\text { Gu sa }\end{array}$ \\
\hline
\end{tabular}

1/ Source of information by county: Treasure - Moshier, R. L. and A. G. Fielder. 1967. Soil survey of Treasure County, Montana. 173 pp.

Big Horn - Meshnick, J. C., et a1. 1972. Unpub1. Soil survey of Big Horn County, Montana. 1086 pp.

2/ Plant abbreviations from Anon. 1969. Coded plant list for the state of Montana. Montana Fish and Game Dept. $93 \mathrm{pp}$. 


\section{Appendix}

Table 16. Location of prairie grouse breeding grounds and male birds attending.

\begin{tabular}{|c|c|c|c|c|c|}
\hline Species & Location & $\begin{array}{l}\text { Date } \\
\text { Located }\end{array}$ & \multicolumn{2}{|c|}{ Hunting } & $\begin{array}{l}\text { Male } \\
\text { Birds }\end{array}$ \\
\hline 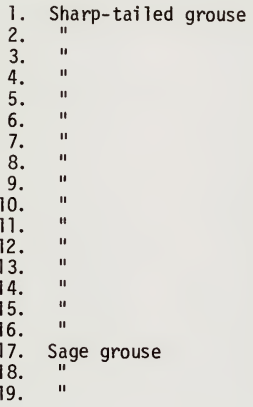 & $\begin{array}{l}\text { TIN, R36E, S24 } \\
\text { TIN, R36E, S36 } \\
\text { T2N, R36E, S } 3 \\
\text { T2N, R36E, S10 } \\
\text { T2N, R37E, S30 } \\
\text { T3N, R36E, S10 } \\
\text { T3N, R37E, S18 } \\
\text { TIN, R37E, S25 } \\
\text { TIN, R38E, S27 } \\
\text { T1N, R38E, S31 } \\
\text { T1N, R38E, S36 } \\
\text { T2N, R37E, S23 } \\
\text { T2N, R38E, S29 } \\
\text { T3N, R37E, S } 1 \\
\text { T4N, R38E, S31 } \\
\text { T5N, R37E, S27 } \\
\text { T2N, R36E, S12 } \\
\text { T3N, R37E, S } 8 \\
\text { T3N, R37E, S27 }\end{array}$ & $\begin{array}{l}4 / 16 / 74 \\
4 / 16 / 74 \\
4 / 23 / 74 \\
4 / 23 / 74 \\
3 / 29 / 74 \\
4 / 1 / 74 \\
4 / 9 / 74 \\
3 / 26 / 74 \\
3 / 26 / 74 \\
3 / 26 / 74 \\
3 / 26 / 74 \\
3 / 27 / 74 \\
3 / 27 / 74 \\
3 / 27 / 74 \\
3 / 27 / 74 \\
3 / 27 / 74 \\
4 / 9 / 74 \\
4 / 9 / 74 \\
3 / 25 / 74\end{array}$ & $\begin{array}{l}720 \\
720 \\
720 \\
720 \\
720 \\
720 \\
720 \\
722 \\
722 \\
722 \\
722 \\
722 \\
722 \\
722 \\
722 \\
722 \\
720 \\
720 \\
722\end{array}$ & $\begin{array}{l}A \\
A \\
V \\
V \\
V \\
V \\
V \\
A \\
V \\
F \\
V \\
V \\
A \\
A \\
A \\
A \\
A \\
A \\
A \\
A \\
V\end{array}$ & $\begin{array}{r}6 \\
20 \\
6 \\
15 \\
16 \\
14 \\
16 \\
12 \\
9 \\
7 \\
15 \\
13 \\
12 \\
16 \\
10 \\
16 \\
16 \\
3 \\
16\end{array}$ \\
\hline
\end{tabular}

1/ $A=$ Airplane, $V=$ Vehicle, $F=$ Foot 
Appendix

Table 17. Population levels of selected species in the Sarpy Creek study area 1900-1990.1/

\begin{tabular}{|c|c|c|c|c|c|c|c|c|c|c|c|c|c|c|c|c|c|c|}
\hline & $\begin{array}{l}\text { Mul } \\
\text { Dee } \\
\text { 0.T. }\end{array}$ & $\begin{array}{l}\text { le } \\
\text { er } \\
\text { N.C. }\end{array}$ & $\begin{array}{l}\text { Whit } \\
\text { tai } \\
\text { Dee } \\
\text { 0.T. }\end{array}$ & $\begin{array}{l}\text { te- } \\
\text { led } \\
\text { er } \\
\text { N.C. }\end{array}$ & $\begin{array}{l}\text { Antel } \\
\text { 0.T. }\end{array}$ & $\begin{array}{l}\text { lope } \\
\text { N.C. }\end{array}$ & $\begin{array}{c}\text { Sag } \\
\text { Grou } \\
0 . T .\end{array}$ & $\begin{array}{l}\text { ge } \\
\text { use } \\
\text { N.C. }\end{array}$ & $\begin{array}{l}\text { Sharp } \\
\text { taile } \\
\text { Grous } \\
0 . T .\end{array}$ & 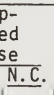 & $\begin{array}{l}\text { Pheas } \\
\underline{0 . T} \text {. }\end{array}$ & $\frac{\operatorname{sant}}{\text { N.C. }}$ & $\frac{\text { Rabbi }}{0 . T}$ & its & $\frac{\text { Mic }}{0 . T}$ & $\begin{array}{l}\text { ce } \\
\text { N.C. }\end{array}$ & $\frac{\text { Coyo }}{0 . T .}$ & $\frac{\text { otes }}{\text { N.C. }}$ \\
\hline $1900-1920$ & 3.71 & - & 5.40 & - & 4.67 & - & 1.17 & - & 1.00 & - & 4.00 & - & 2.33 & - & 2.20 & - & 2.20 & - \\
\hline $1921-1930$ & 4.00 & - & 5.14 & - & 4.88 & - & 1.40 & - & 1.27 & - & 3.80 & - & 1.89 & - & 2.00 & - & 2.25 & - \\
\hline $1931-1940$ & 3.20 & 3.50 & 4.78 & 5.00 & 4.38 & 4.80 & 2.18 & 3.00 & 1.82 & 2.60 & 2.60 & 2.17 & 2.25 & 2.33 & 2.43 & 2.67 & 2.60 & 1.40 \\
\hline $1941-1950$ & 2.36 & 2.27 & 4.44 & 4.14 & 3.67 & 3.80 & 2.67 & 2.67 & 2.67 & 2.36 & 2.64 & 2.50 & 2.56 & 2. 80 & 2.43 & 2.60 & 3.00 & 2.91 \\
\hline $1951-1960$ & 1.91 & 1.68 & 3.67 & 3.42 & 3.10 & 2.33 & 3.33 & 3.00 & 3.00 & 2.19 & 2.36 & 2.33 & 3.00 & 2.35 & 2.57 & 2.54 & 3.73 & 3.58 \\
\hline $1961-1970$ & 2.55 & 2.28 & 3.82 & 3.59 & 3.00 & 3.57 & 3.83 & 3.36 & 2.83 & 2.79 & 2.18 & 2.70 & 3.44 & 2.69 & 2.33 & 2.40 & 3.18 & 2.81 \\
\hline 1971 & 2.55 & 2.63 & 3.91 & 3.80 & 3.20 & 2.68 & 4.08 & 3.64 & 3.08 & 2.86 & 2.45 & 2.74 & 3.78 & 3.27 & 2.33 & 2.48 & 2.91 & 2.33 \\
\hline 1972 & 2.82 & 2.74 & 3.73 & 3.95 & 3.20 & 3.03 & 4.08 & 3.59 & 2.83 & 3.29 & 2.27 & 3.29 & 3.89 & 3.56 & 2.44 & 2. 32 & 2.42 & 2.09 \\
\hline 1973 & 2.91 & 3. 34 & 3.70 & 4.04 & 3.10 & 2.97 & 4.08 & 3.81 & 3.08 & 3.73 & 2.45 & 3.59 & 3.89 & 3.79 & 2.44 & 2.20 & 2.00 & 1.61 \\
\hline 1974 & 3.09 & 3.50 & 3.89 & 4.03 & 3.10 & 3.14 & 4.08 & 4.09 & 3.25 & 3.97 & 2.82 & 3.59 & 4.09 & 3.61 & 2.67 & 2. 31 & 1.67 & 1.50 \\
\hline 1975 & 2.80 & 3.37 & 3.25 & 4.15 & 2.83 & 3.17 & 3.67 & 4.00 & 3.00 & 4.06 & 2.67 & 3.72 & 3.67 & 3.44 & 2.67 & 2.23 & 2.00 & 1.74 \\
\hline $1981-1990$ & - & 3.88 & - & 4.33 & - & 3.69 & - & 4.40 & - & 4.43 & - & 4.19 & - & 3.60 & - & 2.33 & - & 2.18 \\
\hline
\end{tabular}

1) Based on the following scale: 1 - Excellent or very high; 2 - Good or high; 3 - Moderate; 2/ 0.T. = "0ld Timers," N.C. = "Newcomers" 
